\title{
TROPICAL VERTICAL GREENERY SYSTEMS: IRRIGATION SYSTEMS, BIOPHYSICAL CHARACTERISTICS, AND INFLUENTIAL CRITERIA
}

\author{
Chen Wang ${ }^{1}$, Lincoln C. Wood ${ }^{2}$, and Li Tien $\mathrm{Teo}^{3}$
}

\begin{abstract}
Recent studies on vertical greenery systems (VGS) mainly focus on thermal performance, acoustics effects, energy savings and environmental sustainability. There are very few studies on tropical VGS irrigation systems, plants' characteristics, and favorable installation locations, indicating that architectural professionals may lack sufficient guidance to support their design work. Through two descriptive case studies and a questionnaire survey of VGS-related professionals including gardeners, mechanical and electrical engineers, consultants, contractors, and developers, this research developed a knowledgebase for tropical vertical greenery systems irrigation systems and determined the suitability of different types of vertical greenery systems according to the biophysical characteristics of plants. The suitability for various plant characteristics has been identified to help potential users while considering vertical greenery systems irrigation systems. Suitable locations, orientations and microclimatic conditions for vertical greenery systems irrigation systems to prevent system failure have been determined. Further research focused on establishing the technical requirements for irrigation scheduling is recommended to improve the application efficiency.
\end{abstract}

\section{KEYWORDS}

Vertical Greenery System (VGS), irrigation system, building vegetation, green facades, tropics, survey

\section{INTRODUCTION}

Infill development and urban sprawl have caused rapid and extensive depletion of vegetation (Hunter et al., 2014). Vast stretches of natural vegetation have been replaced with concrete buildings and low albedo surfaces, leading to greater awareness of the urban heat island (UHI) effect from reduced evapotranspiration and changes in the thermal properties of surface

1. College of Civil Engineering, Huaqiao University, Xiamen, 361021, P.R.China.

2. Faculty of Business and Law, Auckland University of Technology, Private Bag 92006, Auckland 1142, New Zealand; and School of Information Systems, Curtin University, Perth, Australia.

3. Faculty of Built Environment, University of Malaya, 50603, Kuala Lumpur, Malaysia. Corresponding Author: Distinguished Professor,

Dr. Chen Wang, Email: derekisleon@gmail.com, Tel: 03-7967 6860 
materials used in urban areas (Wong et al., 2010). In response, consumers' awareness of urban sustainability has driven a growing demand for comfortable and healthy living environments (Jim and He, 2011). Greenery constructive systems for buildings offer feasible solutions to urban sustainability, particularly the development of green roofs and green facades (Pérez et al., 2014). To increase the amount of greenery in the city, the Singapore government championed an innovative integration of greenery into built-forms (Wong et al., 2009). Due to the high density of construction within the limited territory, planting on walls emerged as an innovative and rapidly developing technique to re-introduce nature back into urban landscapes (Wong et al., 2010). Wall-based planting has initiated a movement towards sustainable urbanization, forming a key method used in a range of sustainability strategies (Zhang, in press). A range of new sustainable approaches and innovative techniques can be applied to improve the quality of life in urban environments (de Jong et al., 2015); alone, none of these techniques is likely to provide sufficient benefit.

A key element of these emerging urban sustainability techniques is commonly referred to as a vertical greenery system (VGS), designed to allow an urban garden to grow vertically on a building façade. The use of VGS is suitable in urban environments where there is limited space on the ground but where vertical space is abundant (Almusaed, 2011). Numerous ecological and environmental benefits that can have a positive impact on the comfort and well-being in and around buildings have been offered by green façades and living wall systems (LWS) where carrier systems support plants on a façade. The VGS structure allows cooling of the building wall in addition to other benefits that accrue from using green infrastructure, e.g., shading, reflection of solar radiation, convective shielding, thermal insulation, and evapotranspirative cooling (Taha, 1997). The adaptive properties of VGS and the arrangement of the basic VGS components enable designers to change microclimatic conditions on the external building envelope (Šuklje et al., 2013).

The effective use of water is crucial when designing and implementing a VGS system. Almusaed (2011) noted that the use of soil as planting medium in VGS is encouraging for its role as a primary self-sustaining ecosystem, and it can be easily implemented using various wall types. Alternatively, a hydroponic medium containing chemical plant nutrients can sustain the plants, but this may disrupt or destroy the non-hydroponic component of VGS. Implementation of VGS can occur in any location and can be adapted to a range of climatic environments; VGS can be installed either indoors or outdoors and with or without soil. Selection of a plant with a small root system (relative to the patch of soil where the plant is rooted) will lower overall water demand and reduce the likelihood of plant death during a drought (Adams, 2010). Pots of plants lower on an installation can be watered using a flow irrigation system with little waste of water, starting from pots higher on the wall. Meanwhile, water run-off from tempests or storms can be diminished by storing roof water (Almusaed, 2011). It is important that irrigation systems in VGS function effectively as watering is a key element of plant care. Different types of plants and their growing conditions determine the quantity of water required and frequency of watering (Zhang et al., 2014). Watering techniques suited to various types and sizes of green walls include bubblers, soakers, drips or other short-volume techniques (Almusaed, 2011). The complexity of the system can be varied using a basic timer controlled dripper lines or computer-controlled systems managing automatic moisture monitoring, leakage detection, and pressure regulation. A reliable and carefully designed watering system is necessary for long-term success in the use of VGS, as water influences urban climates through both irrigation and the support of urban vegetation (Coutts et al., 2012). 
Mitigation of the impact of water through irrigation associated with the support of urban vegetation has been receiving greater attention in recent years (Coutts et al., 2012). However, many research opportunities relating to VGS technology remain, especially relating to irrigation systems (Köhler, 2008). Pulselli et al. (2014) found that a condition of comprehensive sustainability can be achieved using VGS over a 25 year lifetime, during which time the system can generate further value regarding improving the building energy performance and urban microclimate. However, several factors (e.g., thermal insulation of the building envelope, radioactive properties of external surfaces, thermohydric properties of vegetation species, and the growing medium of the green wall) impact on the heat and moisture transfer through VGS (Djedjig et al., 2015). Therefore, designers must consider a range of parameters when VGS is considered for implementation; for example, the orientation of walls and the water content distribution within the green wall. The biophysical properties of vegetation canopy, as well as the driving potentials established by humidity and temperature gradients between surface and atmosphere, will govern the energy absorption in an ecosystem (Wang et al., 2016). Insufficient research about the impact on the thermal performance of the design elements (e.g., substrates, irrigation systems, and plant containers) require further quantitative and qualitative evaluation to ensure highly effective system designs (Pérez et al., 2014). There are few studies on VGS irrigation systems, plants characteristics, and favorable installation locations; thus, architects in practice struggle to find sufficient scientific guidance to support their design work.

The emerging requirements to improve tropical VGS implementations, the use of appropriate irrigation systems, and plant characteristics motivates the present research. The research focused on developing a tropical VGS irrigation systems knowledgebase and to determine the suitability of different types of VGSs according to the biophysical characteristics of plants, suitable locations, orientations, and microclimatic conditions for VGS implementation to prevent installation failures. Furthermore, the research sought to establish professionals' awareness about the interrelationships between elements used in VGS implemented in the tropics. Therefore, the first aim of this research was to determine the suitability of a range of tropical VGS systems relative to plant and climatic characteristics. The second aim was to establish professionals' awareness of these interrelated factors.

The remainder of this paper is organized as follows. First, a literature review on VGS and irrigation systems is presented, with a focus on plants and water efficiency. Second, the methodology is outlined using two cases and a questionnaire survey of VGS professionals. Third, the Supertrees case and overview of key plant characteristics in the tropics is presented. This is followed by an analysis of survey respondents' evaluation of tropical VGS implementation factors, criteria for VGS irrigation system selection, and other considerations made in the irrigation system selection. Finally, the findings are discussed in relation to existing research, indicating that while respondents were aware of key elements, other important factors relating to VGS (e.g., noise reduction) were not widely appreciated by the respondents.

\section{VERTICAL GREENERY SYSTEM (VGS) AND IRRIGATION SYSTEM}

VGS is a vertical standing, vegetated structure that could be fixed to a building façade or an interior wall (Fernandez-Canero et al., 2011). Significant variables that affect the implementation of vegetation in a building include the time required to install, available space (as this 
impacts on weight, foliage, density, and shape), and weather (Pérez et al., 2014). The system can pose difficulties during maintenance as damage can be caused if it were installed on walls unsuited to supporting a VGS or if it becomes necessary to remove the aggressively growing plants. The potential success of increasing vegetation in the building is dependent on the thickness and mass of the vegetation (Köhler, 2008). Architectural elements with various technical systems are integrated into the overall design of buildings to offer more vegetation planting opportunities (Köhler, 2008). Benefits include a positive impact on the air environment (Köhler, 2008) and the potential to support energy savings due to the shade, insulation, the wind barrier, and the cooling effect that VGS creates (Pérez et al., 2014).

Plants in VGSs can grow against, up, or on feature walls or the building façade; alternatively, they may act as a balcony garden, part of a window shade, or in a vertical hydroponic system. The parameters such as the supporting system, façade orientation, biomass production, climatic factors, and environmental effect must be taken into consideration when selecting the plant species for the different VGS systems.

The design of an irrigation system depends on the type of VGS system. There are three types of VGS systems: support systems, cassette systems, and planter systems. In a support system, structures like wire mesh or cables are used to guide climbing plants and cascading groundcover up the vertical surface. Climber plants can grow using rainwater; therefore, no additional irrigation system is required. However, in a cassette system, the plant growth depends on the growing media contained in modular units (Figure 1) which can be easily mounted on panel cells and attached to various wall surfaces. A greater diversity of plants can be supported in the panel system, and this requires customized irrigation systems. Similar to the cassette system, a planter system can support a greater diversity of plants (supported by an automated irrigation system); it consists of planter boxes (pots) mounted at regular intervals onto a structure or frame and stacked to form comprehensive green wall coverage.

FIGURE 1: Modular units (left) and planter boxes (right); these enable easy and rapid adhesion of plants to walls
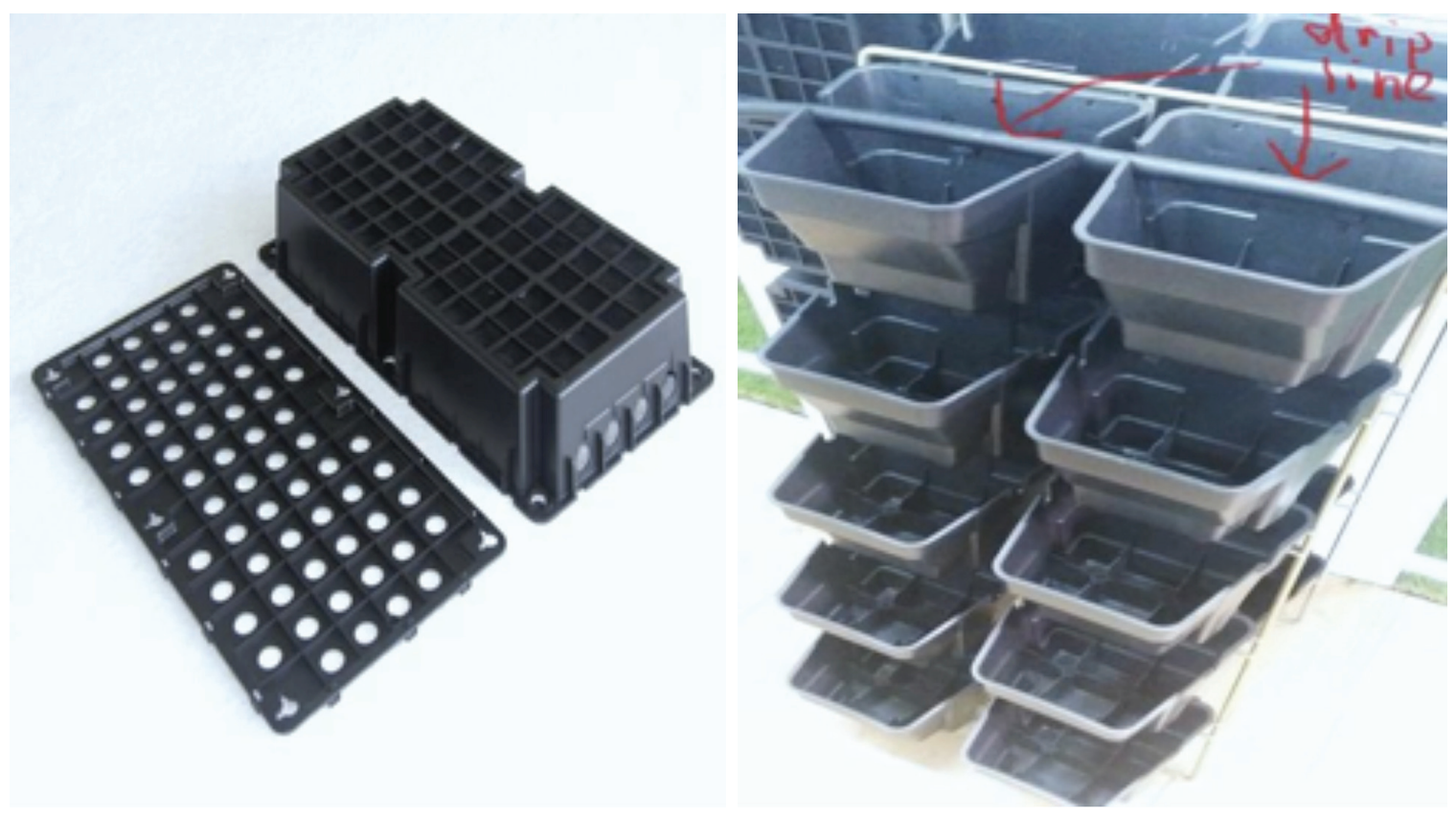
VGS is usually designed to use a drip irrigation system (Figure 2) to maximize the use of water. This technique ensures high irrigation efficiency by ensuring that the substrate can absorb the water supply using drip pipes built into the structure. Drip irrigation allows water to flow drop-by-drop either directly to the root zone directly or through the soil surface. Capillary action in plants bring extract water and distribute through the plant. Hence, the use of sprinklers is not encouraged as it sprays water onto the surface of vertically aligned plants, resulting in water waste. The wicking technique is not commonly applied due to the large gravitational impact on the sucking force of plants from the sponge-like wick. The critical factor to the success of drip irrigation is the even distribution of water to plant roots. Drip emitters distribute water automatically through a drip valve based on the programmed system; thus, it is crucial to determine the spacing of drip emitters to ensure sufficient water absorption in each plant. In this context, several considerations need to be taken into account: the size of the pot (in the planter system) or panel (in the cassette system), building structure, the layout of VGS, plant species, and the location. For instance, if VGS is installed onto an inclined surface, the configuration of emitters must be examined to identify the most appropriate positioning to ensure sufficient changes in water velocity.

FIGURE 2: Drip pipe (left), drip emitter (middle), and drip connectors (right)
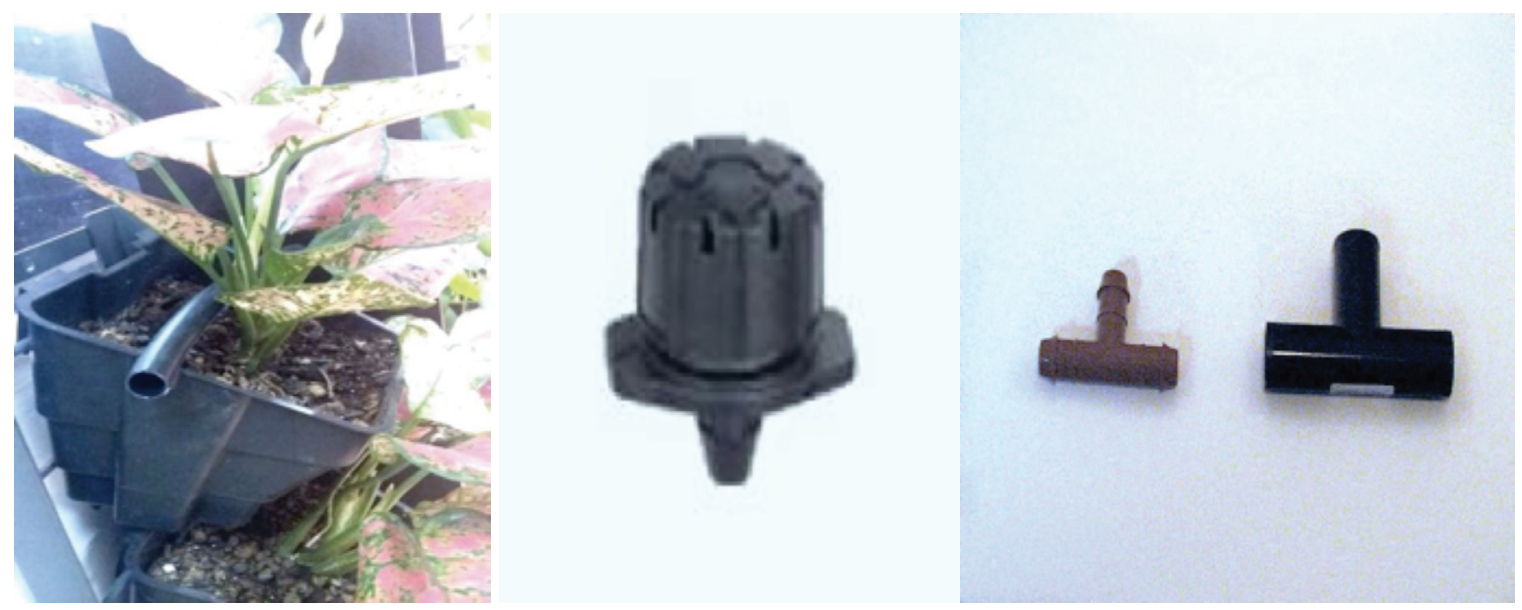

In drip irrigation systems, the watering schedule addresses factors including the watering volume, watering speed, and watering frequency. There are controller and pressure regulators on the valves to adjust and regulate the release of water from the reservoir tank via pumping. A breakout gap in the tank prevents backward contamination, which is commonly called a direct system. For recirculating systems, the key difference is that the water supply is re-circulated from an irrigation tank which collects excess water at the bottom of the wall. Owing to the more complicated design involved in the water drainage collection, this system incurs a higher installation and maintenance cost. It also has a higher risk of fungus attack. Therefore, a direct system is preferred unless there are challenges when using the building drainage outlet.

The use of remote sensors has been largely eliminated from contemporary automated VGS irrigation systems. Less accurate results can be obtained due to the vertical alignment of plants; it becomes hard to identify the height to which one Pascal water pressure will be sufficient to reach as both the height and running the length of drip line need to be considered. Moreover, it is impossible to synchronize the rate of drip emitters for all irrigation zones while 
accounting for the different water demands. The drainage system of VGS is constructed in line with the typical building drainage system. The main building contractor is obliged to include drainage channels in accordance with the design provided by VGS specialists. For an existing building, the construction of a VGS drainage system is similar to that of a new building, but higher installation costs are incurred due to the extensive alteration and addition (A\&A) work. Otherwise, a re-circulating system is used with submersible pumps in the water tank to ensure continuity of the water supply. There is a drainage outlet in the tank for the purpose of cleaning; however, a successful VGS dispenses water evenly at an accurate rate and with precise amounts, so there is less excess water being collected and drained out. The most efficient irrigation technique for VGS is the use of automated drip irrigation. Each component in the system (e.g., drip emitters, valve controllers, or pressure regulators) plays an important role for the system to function correctly. Several considerations (e.g., the location, plant species, and layout) are taken into consideration when developing the watering schedule.

Commonly used VGS installation procedures for planter systems account for the design of the wall-scape and then allow the dimensions (length, height and quantities) of the VGS planter cell to be determined. After that, the points where "J" Profile VGS Brackets (Figure 3) must be mounted are plotted and marked. Meanwhile, the irrigation set-up is planned with an installation of irrigation pipes every three tiers. According to desired dimensions, the VGS bracket and walls are installed. Subsequently, a metal frame is mounted on the wall, and it is followed by mounting of the "J" profile aluminum brackets. Next, the required pots of each variety of plant are added to the VGS planter cell in accordance with the design. To secure the plants and soil with the VGS bar (Figure 3), the two ends of the 'hook latch' of the bar are locked to the bar catch of the VGS planter cell. These exert a pulling force at the center of the bar and re-affirm the inter-locking of the components. The installation is then completed by simply mounting the VGS planter cell to the J-bracket. Starting from the bottom layer and working to the top, the 'mounting catch' of each VGS planter cell is slotted to the latch of the appropriate J-bracket.

FIGURE 3: J-bracket profile for a vertical greenery system (VGS) bracket (left), bar (middle) \& bar catch of vertical greenery system (VGS) planter cell (right)
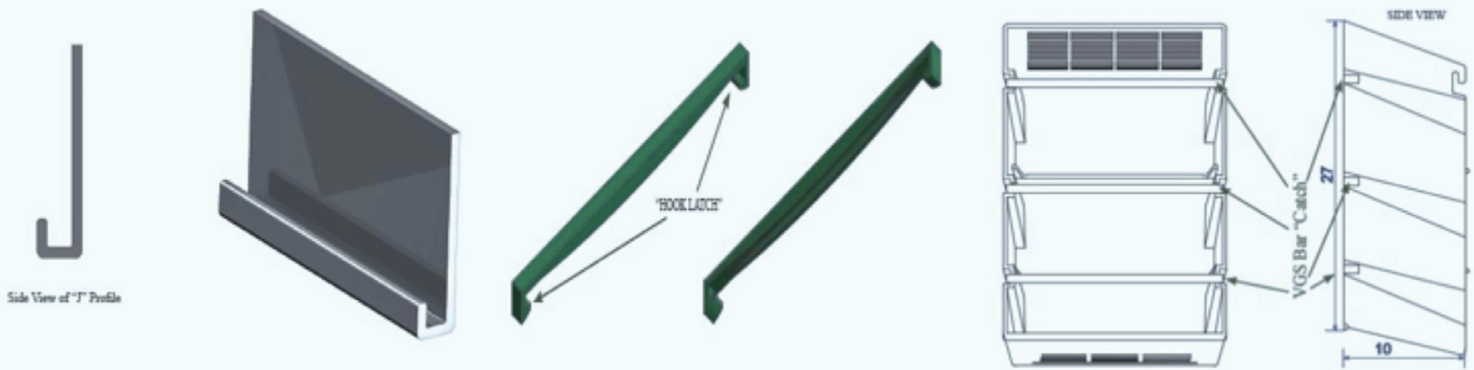

\subsection{VGS Systems}

Vertical greenery systems are classified by the growing methods used (Perini et al., 2012). Each system has its engineering specifications, planting restrictions, positive and negative impacts on the settings, and maintenance requirements. The different requirements means that governmental organizations may need to provide specific policy support for cities and buildings 
to encourage them to retrofit VGS systems to improve sustainable urbanization (Puppim de Oliveira et al., 2013) based on climatic and architectural requirements of a region.

The design concept of support systems for VGS emphasizes the growth of plants on specially designed support structures. The support structures allow climbing plants, cascading groundcovers, or hanging port shrubs to develop as coverings for the desired area of a building façade (Pérez et al., 2014). Support system climbers can be attached to the building using the façade material to provide structural support to the plants (Perini et al., 2012). Climber plants can use structures like steel wire cables, fiberglass mesh, and wooden trellis as supports to create a 'green curtain' (generally termed a double-skin green façade) separated from the wall (Pérez et al., 2014). Based Pérez et al. (2014), there is a type of support system called 'perimeter flowerpots,' where hanging shrubs are planted around the building as a part of the composition of the building surface to create an extensive green curtain. The growing media are another key component of the VGS support system.

Carrier systems are designed to hold the growing media for vertical planting, enabling a greater diversity of plants to be hosted. The system is termed a 'living wall', where plants such as groundcovers, ferns, grasses, sedges, and mosses can be hosted. These systems hold pre-cultivated vegetation fixed to vertical supports or on the wall structure itself (Pérez et al., 2011). It requires only a light structure to be anchored to the building façade, containing a cladding in which plants or grasses are embedded (Mazzali et al., 2013). The carrier that holds the substrate media is constructed from a modular panel which can be constructed from plastics, synthetic fabrics, metal, clay, or geotextile felts (Pérez et al., 2014). Hydroponic cultures using balanced nutrient solutions may be contained in panels to supply food and water to the plant substrate (Dunnett and Kingsbury, 2004). Similar concepts are applied to soil-based living walls, where the growing media is kept in an assortment of modules for plant material sustainability (Almusaed, 2011).

\subsection{Plants in VGS}

Knowledge of plant characteristics is essential to an understanding of various forms of vegetation appropriate for use in a VGS (Almusaed, 2011). The height that plants grow must be considered when constructing green façades using climber plants (Dunnett and Kingsbury, 2004); some climber plants can grow $25 \mathrm{~m}$ high while other species only reach 5-6m. For example, the Boston ivy evergreen (Parthenocissus tricuspidata) and ivy perennial (Hereda sp.) can climb a wall without additional support (Pérez et al., 2014). Köhler (2008) found that these plants have completely covered building façades up to $22 \mathrm{~m}$ high in inner city areas of Berlin and most Central European cities.

Furthermore, it is necessary to take the plant root and shoot structure into account when designing the living wall system. Shallow rooting plants and plants tolerant to water deficiency are preferred as they can survive in a shallow soil environment on a vegetated wall and out-survive any weeds that emerge (Almusaed, 2011). The growing media, with an engineered mixture of lightweight soils and other materials, must be designed to supply sufficient and balanced nutrient solutions to the plant varieties. The mix of species also demands consideration of variables (e.g., microclimatic factors like light, temperature) as the symbiosis between the growing medium and vegetation is a key element in the success of a living wall system (Perini et al., 2012). 


\subsection{Irrigation Techniques and Water Efficiency}

In the agricultural, horticultural, and construction sectors, 'Irrigation Systems' refers to the infrastructure used to deliver water to crops, plants, or lawns. The term 'irrigation' refers to a controlled application of water through man-made systems to supply water when requirements are not satisfied by rainfall (Ertek and Yilmaz, 2014). Irrigation techniques that can be used in VGSs are categorized into three types, surface irrigation, sprinkler irrigation, and micro-irrigation (Pérez et al., 2014).

Irrigation based on a gravity-fed mechanism that enables water to flow to the soil is a surface irrigation system. Distribution of water using an overland flow is used in various application systems such as basins, borders, and furrows (Adamala et al., 2014). The analysis of the relative magnitude of the surface flooding phase and infiltration phase after accumulation is key in the application of surface irrigation systems. Lower capital costs are associated with surface irrigation systems; however, they are more labor intensive and less efficient in water application than other systems. Nevertheless, an initial investment might be increased when extensive land smoothing is required. Hence, land with relatively uniform terrain and gentle slopes (i.e., lower than a 2 percent incline) as well as uniform soils with moderate- to lowinfiltration rates, are most suited to surface irrigation systems (James, 1987). However, surface irrigation systems demonstrate poor efficiency in light-textured and heterogeneous soils due to the variability of water intake rates into the soil (Fereres et al., 2003).

Sprinkler irrigation uses pressured water carried through lines and distribution components, e.g., rotary sprinklers, perforated pipes, and diffusers with permanent water streams. Under pressure, the water is distributed as a form of artificial rain. Sprinkler systems usually operate at pressures ranging from 70 to over $700 \mathrm{kPa}$; i.e., 10 to over 100 psi (James, 1987). Sprinkler systems have high efficiency in water distribution and require little labor during operation. However, the system consumes more energy than other application systems and requires a relatively high capital cost of installation. Sprinkler systems enable permeable soils and easily erodible soils (i.e., land with steep slopes) to be irrigated (James, 1987). Application of water to areas where land leveling is not feasible at the required depth is possible (Fereres et al., 2003). In some regions with arid climates, there is the possibility that strong winds may reduce the uniformity of distribution of sprinkler-applied water, leading to greater loss from spray evaporation and drift (Fereres et al., 2003). The system is adaptable to undulating terrain and lands with shallow soils; however, the former might benefit from land smoothing to support other (more costly) application systems, while the latter would prevent proper land smoothing to support other application systems. Sprinkler systems can be used in fertilizer and chemical applications, crop and soil cooling, and frost protection (James, 1987).

Micro-irrigation involves the application of water to part of the soil in the field at the base of the plant (i.e., the plant root zone), enabling small yet frequent quantities of water to moisten the plant root zone. There are three primary application systems using different principles (viz., dripping water with a one-drop-at-a-time onto the root zone, bubbling water onto land surface in small streamlets, or spraying water as a fine mist over lands surface's portions (James, 1987)) that may be used in a range of micro-irrigation techniques including drip irrigation, trickle irrigation, daily flow irrigation, drop irrigation, and sip irrigation. The control offered by micro-irrigation enables precise application of water and chemicals efficiently (i.e., exact amounts at the most appropriate location), minimizing leaching (Gärdenäs et al., 2005). Micro-irrigation is favored when there are high-value row crops and a limited and expensive water supply (e.g., where water is saline) and it is adaptable to most soils and 
terrains. However, it is expensive to install and difficult to maintain due to the clogging of system components by water with high concentrations of particles, biological materials, and chemicals (James, 1987).

The evaluation of irrigation system performance is dependent on the requirement for water efficiency. The term 'water efficiency' is defined as the ratio between the amount of water used to achieve a purpose and the total amount of water used within the spatial domain. The water input can be controlled through identification of how and where it should be used together with the minimization of water losses. Water losses in irrigation can be attributed to deep percolation, evaporation from crop or soil surfaces, runoff, and spillage (James, 1987). Ertek and Yilmaz (2014) reported extensive adoption of wasteful systems in irrigation that is hard to control (e.g., overhead spray and flood techniques), that cause a significant loss due to evaporation. Irrigation scheduling devices with insufficient accuracy do not apply water based on plant needs; the soil can become overly irrigated. The soil then cannot store additional water and, therefore, a significant amount of water is wasted as drainage or run-off from the surface (Stirzaker, 1999). Low efficiency is inherent within ineffectively designed and managed irrigation systems (Adamala et al., 2014). Irrigation management can be improved by addressing the reliability and accuracy of soil moisture adjustments to produce high-value crops. Soil moisture sensors are essential to secure appropriate amounts of water for irrigation cycles and fertilization; sensors also enabling soil moisture to be held constant and ensure that the needs of the plants are met (Diyana Rosli et al., 2012).

The plant foliage thickness contributes to surface temperature reduction of the building, especially in direct vegetation systems. Where the vegetation layer is separated from the building façade, the foliage density of plants influences the thermal behavior of the building, which is closely linked to the impact of the evapotranspiration ability of different types of plants and their cooling effect (Pérez et al., 2014). In green façades, it is necessary to determine the shadow effect of plants (i.e., the plants' ability to intercept solar radiation) on the system performance. The number of leaf layers, directly linked to the leaf solar transmissivity evolution, is influential regarding the resulting shadow effect of the system. The green layer of the living wall system is correlated with the durability of building materials and, therefore, cannot be neglected as the plants reduce the UV that will fall on the building façade (Wong et al., 2010). Limitations on achievable sizes of green leaves must be considered to avoid the green areas from becoming overly distressed due to potential water loss or heat damage (Almusaed, 2011). The choice of different plant species is important as it influences air flow and temperatures on the building envelope (Perini et al., 2012).

\subsection{Considerations in Choosing Irrigation Systems}

There are several parameters to be taken into account while employing irrigation systems. The physical properties of soils determine the relationship between soil and water (e.g., available water content and permeability) whereas chemical properties of soils interfere with the alkalinity or salinity status of the fluid (e.g., exchangeable sodium and soluble salts). Water demands can be estimated based on soil types, precipitation, and soil moisture retention to support application to the root zone. Physical parameters such as soil depth can be a limiting factor (Albaji et al., 2015). Topography affects the irrigation system adopted in a region. Surface irrigation will give less irrigable area where there is high slope gradient (Albaji et al., 2015). Drip irrigation or sprinkler irrigation is preferred because little or no land leveling is required. Various topographical settings can allow a gravitational head to operate the irrigation system 
(Bhatnagar \& Srivastava, 2003). Water source evaluation is important to identify a reliable water source for successful irrigation; specifically, the total volume and volumetric flow rate of the water source supply must be determined (James, 1987). In arid countries, micro-irrigation and sprinkler irrigation techniques are used extensively to reduce water use as large rivers and other water sources are not widely available. The water requirements of each plant type vary due to climatic and soil conditions (Ertek and Yilmaz, 2014).

Highly efficient modern irrigation technologies (e.g., sprinkler and micro-irrigation systems) have the potential to improve crop production (Ertek and Yilmaz, 2014). To ensure that the applications of an irrigation system are financially viable, modern irrigation techniques may be restricted to high-value crops. Thus, climatic factors (e.g., temperature, relative humidity, and the wind) should be considered as they impact on the irrigation requirements for each crop. Windy conditions will hinder the use of sprinklers system, suggesting the use of drip or surface irrigation in these regions. Sprinkler and drip irrigation are preferred to surface irrigation for regions with a high possibility inconsistent irrigation demands (James, 1987).

\subsection{Contemporary Irrigation Techniques in VGS}

VGS is an effective water-conservation option for urban greening; the system uses half the water that a standard in-ground garden consumes (Hopkins and Goodwin, 2011). Hence, it is essential to design an appropriate irrigation system for different types of VGS once a sustainable water supply is established. For an in-ground green façade system, a low-pressure and low-volume drip system or subsoil drip system is usually adopted. For green wall systems, irrigation is accomplished with hydroponic systems where mechanical irrigation is applied to supply the growing media with water and nutrients. A drip line at the top of the container system irrigates each module by carrying water and nutrients, aided by gravity, with a drip tray incorporated at the bottom to collect and recycle excess water and nutrient from the system (Hopkins and Goodwin, 2011). The efficiency of the fertilizer and irrigation system can be enhanced by drip irrigation allowing precise application of fertilizer and water over a plant, if the system is properly designed (i.e., accounts for emitter spacing, emitter discharge rate, and tape lateral spacing) and well-managed (i.e., the irrigation schedule has been carefully designed) under specified soil and climatic conditions. The emitter is the key component in drip irrigation devices as it moderates the water flow and speed according to the water pressure to maintain a steady flow rate of water-fertilizer on every position of water supply. Water can be distributed uniformly in all irrigation areas by the mechanical adaptive controller (Wei et al., 2003). For efficiency, water sensors monitor moisture levels in VGS and are placed in the root zone where water is required (Hopkins and Goodwin, 2011) because adequate soil moisture optimizes the rate of plant cell metabolism and improves the effectiveness of the application of nutrients (Rahil and Qanadillo, 2015). An irrigation controller can either be an independent system or entirely integrated within the integrated building services. The use of independent irrigation controller systems is desirable in the commercial application of VGS, as they not affected by errors in the building service system and can, therefore, maintain water supply when other problems occur. Control devices monitor the microclimatic conditions (e.g., evaporation, temperature and relative humidity) to maximize the water supply efficiency and improve plant growth rates (Hopkins and Goodwin, 2011).

It is clear that the concepts relating to successful design and implementation of VGS must be understood by professionals when designing and implementing the systems in practice. Therefore, the first aim of this research was to determine the suitability of a range of 
tropical VGS systems, relative to plant and climatic characteristics. The second aim was to establish professionals' awareness of these interrelated factors.

\section{RESEARCH METHODS AND PROCEDURES}

Mixed methods including quantitative and qualitative approaches were employed to achieve the research aim. First, two descriptive case studies based on site visits were undertaken, the results of which informed the design of a questionnaire survey sent to professionals that use VGS. The first step in designing the case study was to establish a rigorous and thoughtful research focus to help guide the research. In this study, irrigation systems in VGS require an in-depth examination through an extensive description of the types, operational methods, and selection criteria. A variety of data gathering methods were used to generate evidence and to describe these complex phenomena. Case studies were conducted to deepen the understanding of how irrigation systems in VGS function and to evaluate the use of complementary systems and components. The biophysical properties of plants were examined according to application suitability. The two cases in this research were the Uniseal Creative Solution Pte Ltd (Singapore) and Supertree Grove, Garden by the Bay (Singapore). The use of two cases studies enhances external validity.

Second, a questionnaire survey was designed and conducted to collect quantitative data on professionals' use of VGS irrigation systems, based on different building structures and locations; i.e., whether they are outdoor or indoor structures. The survey approach was adopted as it reaches a large number of respondents spread across a wide geographical area and at a relatively low cost. This survey was conducted via post services to reach targeted respondents. To produce reliable and valid results, careful considerations were made during the questionnaire design stage and the initial questionnaire was evaluated by other experts to ensure that the questions were comprehensible to increase the validity of the responses (Salant \& Dillman, 1994). A comprehensive list of questions was prepared (presented in Appendix A) and then adjusted to limit the instrument to five pages of questions grouped into five sections in a logical sequence: a) respondent demographics; b) VGS characteristics; c) considerations in VGS irrigation systems; d) selection criteria; and, e) implementation preferences. A Likert-type scale system was used, based on a four-point response to prevent respondents from choosing a neutral option (i.e., the third of a fifth response) that would result in distorted responses. Samples consisted of respondents with different backgrounds in VGS-related industries. VGS-related professionals (viz., gardeners, mechanical and electrical (M\&E) engineers, consultants, contractors, and developers) were expected to have sufficient experience using VGS and possess an in-depth understanding of VGS components.

SPSS (version 16.0) and SmartPLS 2.0 were adopted to assist descriptive analysis and inferential analysis. Partial Least Square Structural Equation Modeling (PLS-SEM) supported further analysis of the survey questionnaire responses. Using the PLS Algorithm, the numbers in the circles show variances of latent variables. Variance above 0.75 is substantial; 0.50 is moderate, and 0.25 is weak. The numbers presented on the arrows are path coefficients, which explain the significance of one variable over another. For a reliability check, an internal consistency reliability test was carried out, where the composite reliability should be 0.6 or higher. For a validity test, Average Variance Extracted (AVE) values confirmed the convergent validity; AVE values exceeding 0.5 indicate sufficient convergent validity. 
470 sets of questionnaires were posted to respondents, and 103 forms were returned. Of the returned surveys, three were not completed and therefore 100 valid surveys were used for analysis, a response rate of $21.3 \%$. Table 1 presents demographic information on respondents including gender, age, education level, and job. There were slightly more female respondents $(\mathrm{n}=51,51 \%)$ than male respondents $(\mathrm{n}=49,49 \%)$. Four age groups were used categorize the respondents: below 20 years old $(n=3,3 \%) ; 21$ to 25 years old $(n=52,52 \%) ; 26$ to 30 years old $(\mathrm{n}=27,27 \%)$; and above 30 years old $(\mathrm{n}=18,18 \%)$. For education levels, most of the respondents have at least some tertiary education $(n=89,89 \%)$; the other respondents are educated to the primary level $(n=3,3 \%)$ or secondary level $(n=8,8 \%)$. To provide assurance that the respondents can provide sufficiently knowledgeable responses about VGS, the respondents' membership of an appropriate profession was evaluated. The sample consisted of architects $(\mathrm{n}=5,5 \%)$, VGS contractors $(\mathrm{n}=37,37 \%)$, quantity surveyors $(\mathrm{n}=8,8 \%)$, VGS consultants $(n=13,13 \%)$, gardeners $(n=30,30 \%)$, and M\&E engineers and consultants $(n=7,7 \%)$.

TABLE 1. Demographic information of respondents

\begin{tabular}{|c|c|c|}
\hline Gender & \begin{tabular}{|c} 
Frequency (and \\
percentage as \\
there were 100 \\
valid responses)
\end{tabular} & Percent $(\%)$ \\
\hline Male & 49 & 49 \\
\hline Female & 51 & 51 \\
\hline \multicolumn{3}{|l|}{ Age } \\
\hline Below 20 & 3 & 3 \\
\hline 21 to 25 & 52 & 52 \\
\hline 26 to 30 & 27 & 27 \\
\hline 31 and above & 18 & 18 \\
\hline \multicolumn{3}{|l|}{ Education } \\
\hline Primary & 3 & 3 \\
\hline Secondary & 8 & 8 \\
\hline Tertiary & 89 & 89 \\
\hline \multicolumn{3}{|l|}{ Job } \\
\hline Architects & 5 & 5 \\
\hline VGS Contractors & 37 & 37 \\
\hline Quantity Surveyors & 8 & 8 \\
\hline VGS Consultants & 13 & 13 \\
\hline Gardeners & 30 & 30 \\
\hline M\&E Engineers and Consultants & 7 & 7 \\
\hline
\end{tabular}




\section{CASE STUDY ANALYSIS AND RESULTS}

The Supertree Grove case in Singapore was selected to allow an examination of the most recently used structural specifications of VGS (Supertrees). The Uniseal Creative Solution Pte Ltd case uses the latest VGS irrigation systems. Uniseal Creative Solution Pte Ltd is located at 31 Mandai Estate, Innovation Place, IMMEDIA \#06-05/06, 729933, Singapore. The Supertree Grove Garden by the Bay is located at 8 Marina Gardens Drive, 018953, Singapore. All the directors involved in establishing the specifications used in these case studies have more than six years' experience in VGS products.

\subsection{Supertrees Specifications}

The Supertrees are optimized and carefully integrated systems that share similarities with other large-scale tropical VGS implementations. Supertrees are unique artificial trees with a height of 25- to 50-metres, consisting of a variety of plant species that form a living skin. They consist of four parts: the reinforced concrete core, trunk, planting panels of living skin, and canopy. All hardware elements are crucial in allowing the structure to fulfill the role of VGS as man-made mechanical shelter. The reinforced core is fitted with a reservoir tank the top to collect rainwater for electricity generation. There are photovoltaic cells that harvest solar energy. Also, solar thermal collectors are installed to absorb external heat. Pumping pipes and air venting ducts are installed along the trunk to facilitate water flow and heat flow respectively. A turbine is fitted above the base to aid electricity generation. The steel framework holding planting panels of living skin is featured on the trunk, supporting the canopies to provide a home to a variety of plant species that provide daytime shade. The large canopies also operate as temperature moderators by absorbing and dispersing heat. In a Supertree fitted with a rainwater tank at the top, water is collected to generate water flow by shifting energy through turbines that create electricity during the night to continue to sustain the garden site. Photovoltaic cells provide lighting, electricity, and power water-focused technology within the conservatories below. Meanwhile, the solar thermal collector absorbs and transmits external heat to the dehumidifier plant to support the shading effect. There are also Supertrees functioning with warm and moist air intakes, where the air is passed through a dehumidifier plant for dispersal. Some Supertrees are used to exhaust hot air from the dehumidifier plant up the tree to be purged into the atmosphere.

To irrigate the living skin of Supertrees, drip pipes are installed along each planting panel mounted on the steel framework. Pressure-based compensative systems are crucial to the even distribution of water throughout the panels as they overcome limitations imposed by the structural height. The watering schedule is programmed and controlled by water sensors in the reservoir tank that collects the rainwater, similar to how real trees absorb rainwater for growth. Plants on the living skin consist of exotic ferns, vines, orchids, and a vast collection of bromeliads; e.g., Tillandsia. All plant species have their unique characteristics; e.g., evergreen flowering plants like Tillandsia can grow without soil while attached to other plants as they can absorb water and nutrients through leaves. The resulting Supertree Grove is a uniquely designed, vertical garden resembling a series of giant trees. The mechanical form of trees enables contemporary VGS technology to provide cooling and shading for human comfort. Each component in VGS was used in an integrated manner to maximize the ecofriendly effect of the Supertrees (Figure 4). 


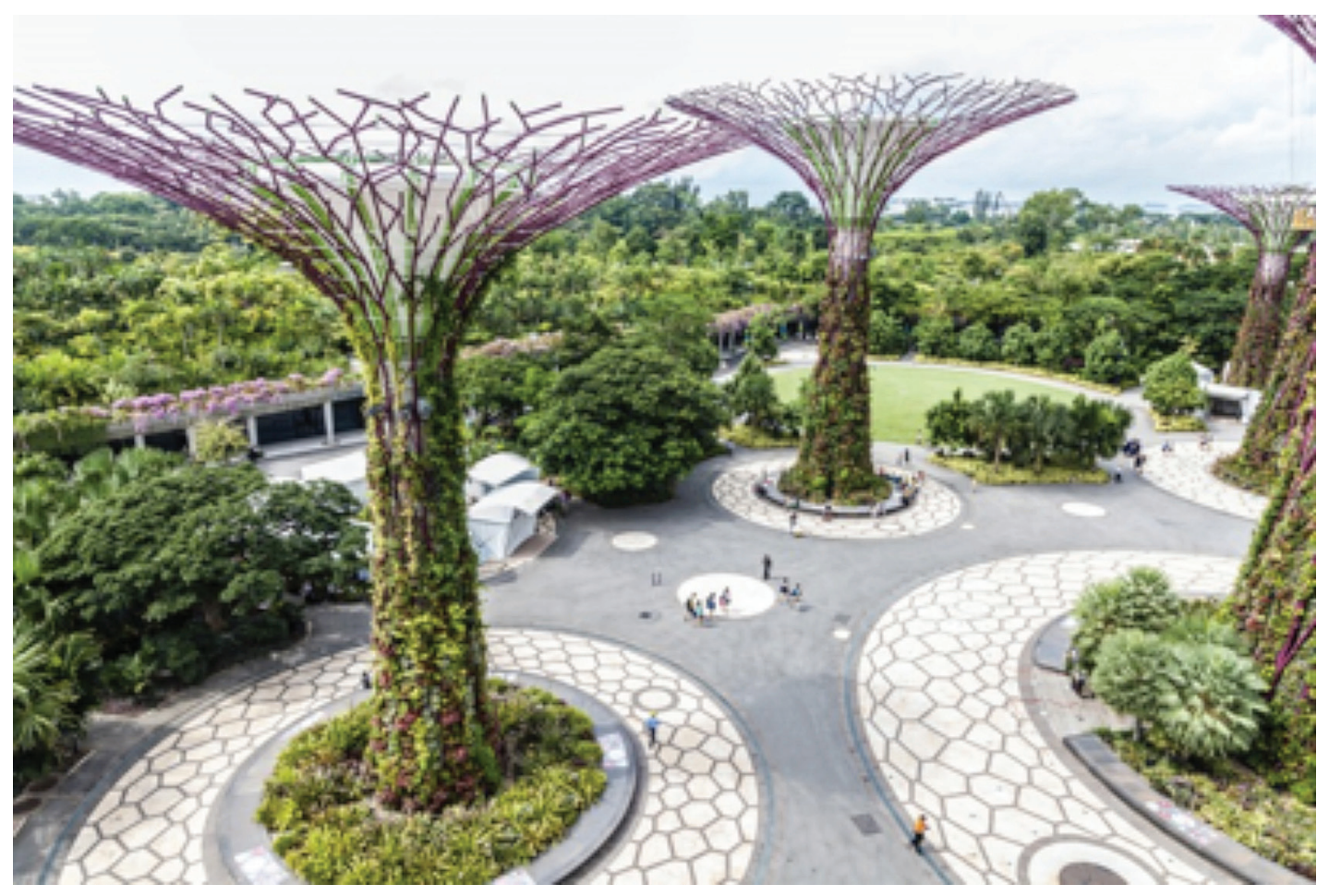

From the Supertrees case, it is clear that careful and thoughtful design is required for VGS systems in the tropics. The integrated nature of the many considerations must be understood. Importantly, the characteristics of plants used must be carefully considered.

\subsection{Biophysical Characteristics of VGS Plants}

The information in this section was collected from the interview section in the two descriptive case studies through site visit. However, since the information and documentation provided by the interviewees except the photos were also secondary data taken from other sources, the original sources were searched and cited here to give credit to the original authors. There is a wide range of plants suitable for installation in VGS structures. Several factors need to be considered in choosing the plants. There are four types of light conditions: a) sun (i.e., direct sunlight with continuous exposure of at least six hours per day); b) partial sun (i.e., filtered light or no direct light with most sunlight during the morning or afternoon hours when the light is weaker; sometimes called 'light shade'); c) partial shade (i.e., filtered light beneath trees with high limbs, usually offering some protection from direct afternoon sun); and, d) full shade, i.e., a dense shade that does not allow penetration by direct light (Mattis \& Hershey, 1992; Yu et al., 2009; Ren et al. 2016; Morton, 1957; Wilde et al., 2012; Hvoslef-Eide, 1991; Woltering, 1987; Pandey et al., 2015; Vogelezang, 1991; Alaba \& Chichioco-Hernandez, 2014). Moisture requirements are categorized by plant types; e.g., outdoor plants or indoor plants. The following terms provide indications of the watering needs for both plant types: a) normal (soil is kept evenly moist and regularly watered to a depth of 18 inches, yet it periodically dries out in the top seven inches between watering); and, b) moist and well-drained (soil is moist but not soggy; excess moisture is allowed to drain away due to the soil texture). Most plants 
like about one inch of water per week (Mattis \& Hershey, 1992; Yu et al., 2009; Ren et al. 2016; Morton, 1957; Wilde et al., 2012; Hvoslef-Eide, 1991; Woltering, 1987; Pandey et al., 2015; Vogelezang, 1991; Alaba \& Chichioco-Hernandez, 2014)..

For outdoor plants, regular watering is important to ensure average water demand is met. Watering is necessary when normal rainfall is insufficient to provide one inch of water. Normal watering is applied in outdoor plants to ensure desirable growth. However, for indoor plants, watering is undertaken until the soil is completely saturated and excess water runs out of the bottom of the pot. Adequate water is supplied for good plant health to ensure plants maintain their almost $90 \%$ composition of water. The watering frequency is important to indoor plants as it ensures thorough water saturation around the roots. Plants should be chosen for their light and moisture requirement compatibility with the conditions where they will be installed (Mattis \& Hershey, 1992; Yu et al., 2009; Ren et al. 2016; Morton, 1957; Wilde et al., 2012; Hvoslef-Eide, 1991; Woltering, 1987; Pandey et al., 2015; Vogelezang, 1991; Alaba \& Chichioco-Hernandez, 2014).

Temperature can be a limiting factor that inhibits plant growth due to the direct influence on biochemical processes; e.g., photosynthesis, transpiration, or respiration. The rate of these processes increases with an increase in temperature until a maximum threshold is reached. Optimal plant growth usually occurs in a fairly narrow range from 60 to 100 degree F. Meanwhile, soil organisms' health can be affected by changes in the soil $\mathrm{pH}$ level (Mattis \& Hershey, 1992; Yu et al., 2009; Ren et al. 2016; Morton, 1957; Wilde et al., 2012; HvoslefEide, 1991; Woltering, 1987; Pandey et al., 2015; Vogelezang, 1991; Alaba \& Chichioco-Hernandez, 2014). Owing to the limited volume and shallow depth provided by VGS structures, the growing media must be amended to provide appropriate physical and chemical properties for plant growth. Thin VGS profiles are essential to minimize the loading and maintenance needs. Drainage, water holding capacity, aeration, and densities must be considered. Soilless growing media, developed with formulated planting mix or nutrient solutions in hydroponics, are often employed. The planting mix is formulated with a high water content retention property to ensure plants remain hydrated while having a high permeability to allow drainage to keep roots aerated and prevent the mix from becoming waterlogged. Nutrient solutions are prepared proportionately regarding water salinity, nutrients concentration, and $\mathrm{pH}$ value (Mattis \& Hershey, 1992; Yu et al., 2009; Ren et al. 2016; Morton, 1957; Wilde et al., 2012; Hvoslef-Eide, 1991; Woltering, 1987; Pandey et al., 2015; Vogelezang, 1991; Alaba \& Chichioco-Hernandez, 2014).

The biggest challenge to the success of VGS is the growth against gravity. The vertical alignment of plants causes the substrate media to dry rapidly, contributing to high evaporation rates. Drought tolerant species (e.g., foxtail fern) are a better choice in VGS, although the system is fully irrigated; however, it is possible to grow a wide range of plants with sufficient irrigation and an appropriate planting media design. Plants' characteristics are crucial determinants of their growth behaviors in VGS. There are several criteria to be taken into account in the process of plant selection, e.g., environmental factors, growing media, and the watering schedule (Mattis \& Hershey, 1992; Yu et al., 2009; Ren et al. 2016; Morton, 1957; Wilde et al., 2012; Hvoslef-Eide, 1991; Woltering, 1987; Pandey et al., 2015; Vogelezang, 1991; Alaba \& Chichioco-Hernandez, 2014). Other important factors that must be considered during VGS planning include the type of systems, intended planting concept, budget, and the expected degree of maintenance. 
TABLE 2. Biophysical characteristics of plants (photos taken by researchers). "V"= vital and "VV"= very vital.

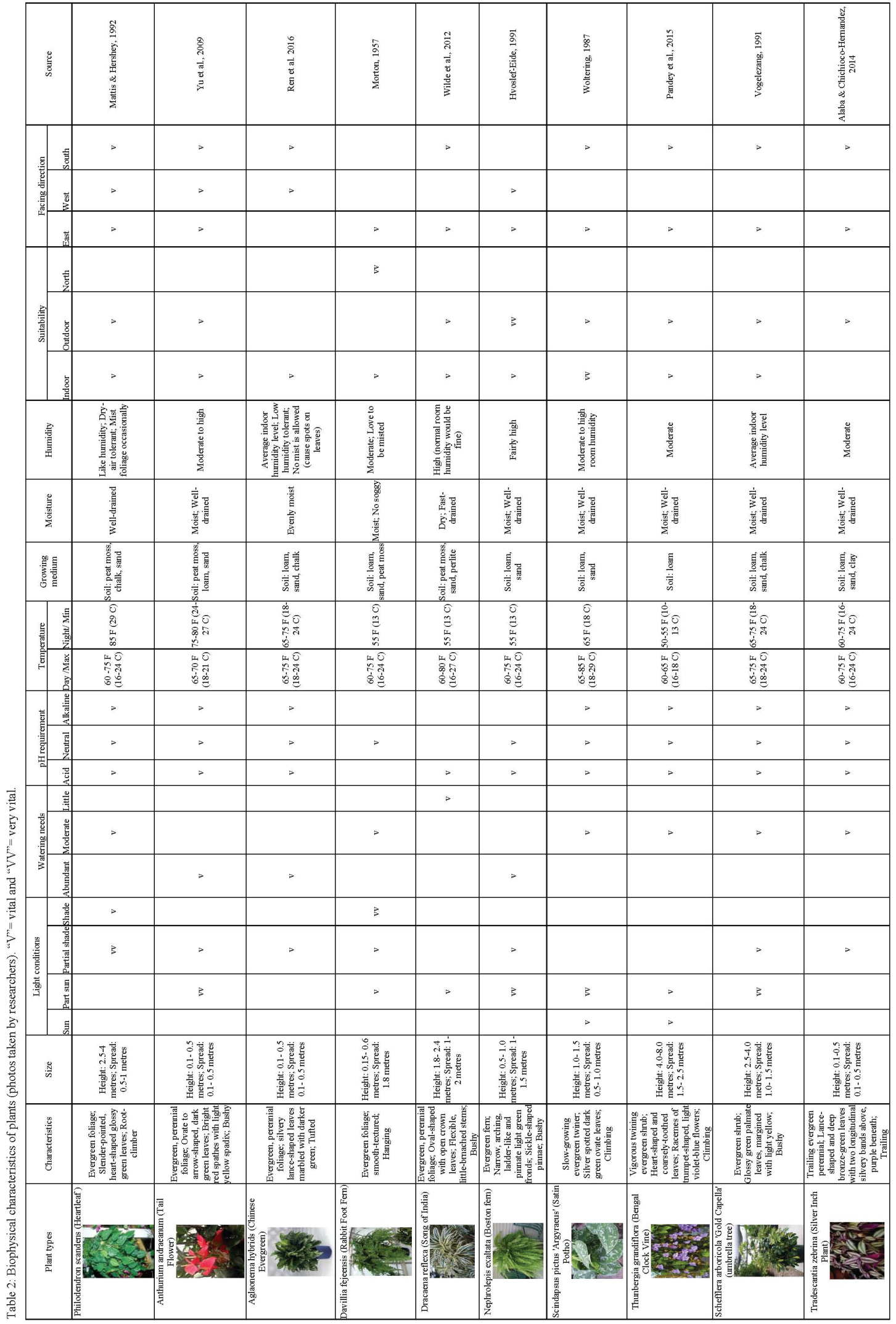


Table 2 summarizes several critical biophysical characteristics of plants in VGS. Implementation of vegetation in buildings is affected by variables including the space available and plants' weight, foliage, and shape. Parameters such as the façade orientation, environmental effect, and climatic factors are considered during the selection of plant species for VGS installation. Most plants in VGS are shallow rooting and water-deficient tolerant because as weeds fail in the shallow soil environment. Meanwhile, soil depth impacts on the irrigation requirements and the mixture of growing media directly relates to plant moisture and watering needs. Sandy soil with low water storage capacity and high infiltration rate are employed in plants that must be well-drained. The chemical properties of soil (e.g., alkalinity or salinity status) and the climatic situation will exert influence on their water requirements. Water demands are estimated based on soil types, precipitation, and soil moisture retention to establish the zones for efficient water application to roots (Mattis \& Hershey, 1992; Yu et al., 2009; Ren et al. 2016; Morton, 1957; Wilde et al., 2012; Hvoslef-Eide, 1991; Woltering, 1987; Pandey et al., 2015; Vogelezang, 1991; Alaba \& Chichioco-Hernandez, 2014).

\section{ANALYSIS AND FINDINGS FROM SURVEY}

The analysis of the survey responses indicated that respondents were more familiar with the outdoor application of VGS (78\%) than the indoor application (22\%). Table 3 ranks the importance of considerations in VGS irrigation systems. Water volume and water frequency has the highest mean value at 3.36, whereas planter cell design (the tray system) has the lowest mean value at 2.77 .

TABLE 3. Importance of Considerations in Vertical Greenery System (VGS) Irrigation Systems

\begin{tabular}{|l|l|l|l|l|}
\hline Consideration & Mean & Std. Dev. & Median & Rank \\
\hline Water volume and water frequency & 3.36 & .612 & 3.00 & 1 \\
\hline Timer-controlled pumping system & 3.15 & .657 & 3.00 & 2 \\
\hline Gravitational force due to vertical alignment & 3.10 & .732 & 3.00 & 3 \\
\hline Soil sensor (i.e. temperature, pH, moisture etc.) & 2.94 & .694 & 3.00 & 4 \\
\hline Rooting materials (e.g. coconut husk and felt) & 2.90 & .718 & 3.00 & 5 \\
\hline Planter cell design (tray system) & 2.77 & .737 & 3.00 & 6 \\
\hline
\end{tabular}

There are many criteria that professionals consider when selecting VGS irrigation systems, as shown in Table 4. The mean value of "maintenance regime" ( $\mu=3.53)$ is slightly higher than "installation cost" $(\mu=3.51)$, followed by "effectiveness of water drainage" $(\mu=$ 3.40), "dimensions of VGS" ( $\mu=3.37)$, "irrigation frequency" $(\mu=3.19)$, "aesthetic requirement" ( $\mu=3.16)$, "types of plants" $(\mu=3.11)$, "application location" $(\mu=3.06)$, "geographical location" ( $\mu=2.92)$, and "elevation" concerning the direction $(\mu=2.87)$.

Table 5 evaluates key factors relevant to the VGS implementation in buildings. Most respondents prioritize efforts to "improve ambient air quality" $(\mu=3.35)$, followed by the objectives to "reduce ambient temperature" and to ensure "sustainability considerations" are met $(\mu=3.28)$. Respondents do not think "noise reduction" $(\mu=2.38)$ is an important factor for VGS implementation.

Table 6 determines the preferred locations on VGS irrigation system. According to the mean values, the "building façade" is most preferred, followed by use of outdoor building columns, rooftop areas or balcony, and indoor areas. 
TABLE 4. Criteria in Choosing Vertical Greenery System (VGS) Irrigation Systems

\begin{tabular}{|l|l|l|l|l|}
\hline Criteria & Mean & Std. Dev. & Median & Rank \\
\hline Maintenance regime & 3.53 & .594 & 4.00 & 1 \\
\hline Installation cost & 3.51 & .674 & 4.00 & 2 \\
\hline Effectiveness of water drainage & 3.40 & .586 & 3.00 & 3 \\
\hline Dimensions of VGS (height, length and width) & 3.37 & .800 & 4.00 & 4 \\
\hline Irrigation frequency & 3.19 & .662 & 3.00 & 5 \\
\hline Aesthetic requirement & 3.16 & .662 & 3.00 & 6 \\
\hline Types of plants & 3.11 & .665 & 3.00 & 7 \\
\hline Application (indoor or outdoor) & 3.06 & .736 & 3.00 & 8 \\
\hline Geographical location & 2.92 & .774 & 3.00 & 9 \\
\hline Elevation (north, south, east, west) & 2.87 & .761 & 3.00 & 10 \\
\hline
\end{tabular}

TABLE 5. Factors for Vertical Greenery System (VGS) Implementation in Building

\begin{tabular}{|l|l|l|l|l|}
\hline Factor & Mean & Std. Deviation & Median & Rank \\
\hline Improve ambient air quality & 3.35 & .575 & 3.00 & 1 \\
\hline Reduce ambient temperature & 3.28 & .570 & 3.00 & 2 \\
\hline Sustainability consideration & 3.28 & .552 & 3.00 & 2 \\
\hline Provide aesthetic & 3.09 & .712 & 3.00 & 3 \\
\hline Provide energy saving & 2.77 & .886 & 3.00 & 4 \\
\hline Increase marketing value of building & 2.67 & .817 & 3.00 & 5 \\
\hline Elevation (north, south, east, west) & 2.65 & .687 & 3.00 & 6 \\
\hline Noise reduction & 2.38 & .919 & 2.00 & 7 \\
\hline
\end{tabular}

TABLE 6. Most Suitable Location for Vertical Greenery System (VGS) Irrigation System

\begin{tabular}{|l|l|l|l|l|}
\hline Location & Mean & Std. Deviation & Median & Rank \\
\hline As building facade & 3.40 & .636 & 3.00 & 1 \\
\hline Place at balcony / rooftop area & 2.94 & .763 & 3.00 & 2 \\
\hline As column of building (outdoor) & 2.82 & .833 & 3.00 & 3 \\
\hline Place at indoor area & 2.21 & .891 & 2.00 & 4 \\
\hline
\end{tabular}


Different building locations and structures were used as independent variables to evaluate whether there is any difference in the locations and structures when professionals consider the VGS implementation factors, criteria in choosing VGS irrigation system, and considerations in VGS irrigation systems. Table 7 indicates that both "provide aesthetic" $(p=0.018)$ and "improve ambient air quality" $(p=0.005)$ are significant to the "building façade" option. Only one factor, "directional elevation" $(p=0.042)$ shows significance related to "outdoor building column". There is a statistically significant association between "reduce ambient temperature" $(p=0.005)$ and "balcony/rooftop area". The independent variable "indoor area" shows a significant relationship with "noise reduction" $(p=0.000)$ and "increase marketing value of building" $(p=0.002)$.

TABLE 7. ANOVA test of Vertical Greenery System (VGS) implementation factors relative to different building locations

\begin{tabular}{|c|c|c|c|c|c|c|}
\hline \multicolumn{7}{|c|}{ a) Building Facade } \\
\hline & & Sum of Squares & df & Mean Square & $\mathrm{F}$ & Sig. \\
\hline \multirow[t]{3}{*}{ Provide aesthetic } & Between Groups & 3.978 & 2 & 1.989 & 4.175 & .018 \\
\hline & Within Groups & 46.212 & 97 & .476 & & \\
\hline & Total & 50.190 & 99 & & & \\
\hline \multirow[t]{3}{*}{ Improve ambient air quality } & Between Groups & 3.447 & 2 & 1.723 & 5.705 & .005 \\
\hline & Within Groups & 29.303 & 97 & .302 & & \\
\hline & Total & 32.750 & 99 & & & \\
\hline \multirow[t]{3}{*}{ Reduce ambient temperature } & Between Groups & 1.522 & 2 & .761 & 2.409 & .095 \\
\hline & Within Groups & 30.638 & 97 & .316 & & \\
\hline & Total & 32.160 & 99 & & & \\
\hline \multirow[t]{3}{*}{ Provide energy saving } & Between Groups & .716 & 2 & .358 & .451 & .638 \\
\hline & Within Groups & 76.994 & 97 & .794 & & \\
\hline & Total & 77.710 & 99 & & & \\
\hline \multirow[t]{3}{*}{ Noise reduction } & Between Groups & 3.452 & 2 & 1.726 & 2.090 & .129 \\
\hline & Within Groups & 80.108 & 97 & .826 & & \\
\hline & Total & 83.560 & 99 & & & \\
\hline \multirow[t]{3}{*}{ Increase marketing value of building } & Between Groups & .258 & 2 & .129 & .190 & .827 \\
\hline & Within Groups & 65.852 & 97 & .679 & & \\
\hline & Total & 66.110 & 99 & & & \\
\hline \multirow[t]{3}{*}{ Elevation (north, south, east, west) } & Between Groups & 1.239 & 2 & .619 & 1.320 & .272 \\
\hline & Within Groups & 45.511 & 97 & .469 & & \\
\hline & Total & 46.750 & 99 & & & \\
\hline \multirow[t]{3}{*}{ Sustainability consideration } & Between Groups & .266 & 2 & .133 & .432 & .651 \\
\hline & Within Groups & 29.894 & 97 & .308 & & \\
\hline & Total & 30.160 & 99 & & & \\
\hline \multicolumn{7}{|c|}{ b) Outdoor Building Column } \\
\hline & & Sum of Squares & df & Mean Square & $\mathrm{F}$ & Sig. \\
\hline \multirow[t]{3}{*}{ Provide aesthetic } & Between Groups & .880 & 3 & .293 & .571 & .635 \\
\hline & Within Groups & 49.310 & 96 & .514 & & \\
\hline & Total & 50.190 & 99 & & & \\
\hline \multirow[t]{3}{*}{ Improve ambient air quality } & Between Groups & .674 & 3 & .225 & .673 & .571 \\
\hline & Within Groups & 32.076 & 96 & .334 & & \\
\hline & Total & 32.750 & 99 & & & \\
\hline
\end{tabular}




\begin{tabular}{|c|c|c|c|c|c|c|}
\hline \multirow[t]{3}{*}{ Reduce ambient temperature } & Between Groups & 2.310 & 3 & .770 & 2.476 & .066 \\
\hline & Within Groups & 29.850 & 96 & .311 & & \\
\hline & Total & 32.160 & 99 & & & \\
\hline \multirow[t]{3}{*}{ Provide energy saving } & Between Groups & .598 & 3 & .199 & .248 & .862 \\
\hline & Within Groups & 77.112 & 96 & .803 & & \\
\hline & Total & 77.710 & 99 & & & \\
\hline \multirow[t]{3}{*}{ Noise reduction } & Between Groups & 1.369 & 3 & .456 & .533 & .661 \\
\hline & Within Groups & 82.191 & 96 & .856 & & \\
\hline & Total & 83.560 & 99 & & & \\
\hline \multirow[t]{3}{*}{ Increase marketing value of building } & Between Groups & 1.257 & 3 & .419 & .620 & .604 \\
\hline & Within Groups & 64.853 & 96 & .676 & & \\
\hline & Total & 66.110 & 99 & & & \\
\hline \multirow[t]{3}{*}{ Elevation (north, south, east, west) } & Between Groups & 3.818 & 3 & 1.273 & 2.846 & .042 \\
\hline & Within Groups & 42.932 & 96 & .447 & & \\
\hline & Total & 46.750 & 99 & & & \\
\hline \multirow[t]{3}{*}{ Sustainability consideration } & Between Groups & .498 & 3 & .166 & .537 & .658 \\
\hline & Within Groups & 29.662 & 96 & .309 & & \\
\hline & Total & 30.160 & 99 & & & \\
\hline \multicolumn{7}{|c|}{ c) Balcony/ Rooftop Area } \\
\hline & & Sum of Squares & df & Mean Square & $F$ & Sig. \\
\hline \multirow[t]{3}{*}{ Provide aesthetic } & Between Groups & 1.943 & 3 & .648 & 1.289 & .283 \\
\hline & Within Groups & 48.247 & 96 & .503 & & \\
\hline & Total & 50.190 & 99 & & & \\
\hline \multirow[t]{3}{*}{ Improve ambient air quality } & Between Groups & 1.774 & 3 & .591 & 1.832 & .146 \\
\hline & Within Groups & 30.976 & 96 & .323 & & \\
\hline & Total & 32.750 & 99 & & & \\
\hline \multirow[t]{3}{*}{ Reduce ambient temperature } & Between Groups & 4.027 & 3 & 1.342 & 4.580 & .005 \\
\hline & Within Groups & 28.133 & 96 & .293 & & \\
\hline & Total & 32.160 & 99 & & & \\
\hline \multirow[t]{3}{*}{ Provide energy saving } & Between Groups & 1.499 & 3 & .500 & .629 & .598 \\
\hline & Within Groups & 76.211 & 96 & .794 & & \\
\hline & Total & 77.710 & 99 & & & \\
\hline \multirow[t]{3}{*}{ Noise reduction } & Between Groups & 2.408 & 3 & .803 & .950 & .420 \\
\hline & Within Groups & 81.152 & 96 & .845 & & \\
\hline & Total & 83.560 & 99 & & & \\
\hline \multirow[t]{3}{*}{ Increase marketing value of building } & Between Groups & 2.254 & 3 & .751 & 1.130 & .341 \\
\hline & Within Groups & 63.856 & 96 & .665 & & \\
\hline & Total & 66.110 & 99 & & & \\
\hline \multirow[t]{3}{*}{ Elevation (north, south, east, west) } & Between Groups & .712 & 3 & .237 & .495 & .686 \\
\hline & Within Groups & 46.038 & 96 & .480 & & \\
\hline & Total & 46.750 & 99 & & & \\
\hline \multirow[t]{3}{*}{ Sustainability consideration } & Between Groups & 2.019 & 3 & .673 & 2.296 & .083 \\
\hline & Within Groups & 28.141 & 96 & .293 & & \\
\hline & Total & 30.160 & 99 & & & \\
\hline
\end{tabular}




\begin{tabular}{|c|c|c|c|c|c|c|}
\hline \multicolumn{7}{|c|}{ d) Indoor Area } \\
\hline & & Sum of Squares & $\mathrm{df}$ & Mean Square & $\mathrm{F}$ & Sig. \\
\hline \multirow[t]{3}{*}{ Provide aesthetic } & Between Groups & 2.732 & 3 & .911 & 1.842 & .145 \\
\hline & Within Groups & 47.458 & 96 & .494 & & \\
\hline & Total & 50.190 & 99 & & & \\
\hline \multirow[t]{3}{*}{ Improve ambient air quality } & Between Groups & .451 & 3 & .150 & .447 & .720 \\
\hline & Within Groups & 32.299 & 96 & .336 & & \\
\hline & Total & 32.750 & 99 & & & \\
\hline \multirow[t]{3}{*}{ Reduce ambient temperature } & Between Groups & 1.618 & 3 & .539 & 1.695 & .173 \\
\hline & Within Groups & 30.542 & 96 & .318 & & \\
\hline & Total & 32.160 & 99 & & & \\
\hline \multirow[t]{3}{*}{ Provide energy saving } & Between Groups & 1.718 & 3 & .573 & .723 & .540 \\
\hline & Within Groups & 75.992 & 96 & .792 & & \\
\hline & Total & 77.710 & 99 & & & \\
\hline \multirow[t]{3}{*}{ Noise reduction } & Between Groups & 17.138 & 3 & 5.713 & 8.256 & .000 \\
\hline & Within Groups & 66.422 & 96 & .692 & & \\
\hline & Total & 83.560 & 99 & & & \\
\hline \multirow[t]{3}{*}{ Increase marketing value of building } & Between Groups & 9.120 & 3 & 3.040 & 5.121 & .002 \\
\hline & Within Groups & 56.990 & 96 & .594 & & \\
\hline & Total & 66.110 & 99 & & & \\
\hline \multirow[t]{3}{*}{ Elevation (north, south, east, west) } & Between Groups & 1.923 & 3 & .641 & 1.373 & .256 \\
\hline & Within Groups & 44.827 & 96 & .467 & & \\
\hline & Total & 46.750 & 99 & & & \\
\hline \multirow[t]{3}{*}{ Sustainability consideration } & Between Groups & .306 & 3 & .102 & .328 & .805 \\
\hline & Within Groups & 29.854 & 96 & .311 & & \\
\hline & Total & 30.160 & 99 & & & \\
\hline
\end{tabular}

Table 8 presents ANOVA test results on the criteria in choosing VGS irrigation system against different building locations. Three criteria ("installation cost" ( $p=0.006)$, "directional elevation" ( $p=0.019)$, and "dimension of VGS" $(p=0.000)$ are significantly associated with "building façade." While taking "outdoor building column" as the independent variable, only the "dimension of VGS concerning height, width and length of the system" ( $p=0.000)$ is statistically relevant. There is no significant effect when the factors are evaluated against the "balcony/rooftop area." The factor "effectiveness of water drainage" is relevant to "indoor area" with a significant value of $p=0.012$.

TABLE 8. Criteria in choosing Vertical Greenery System (VGS) irrigation systems against different building locations

\begin{tabular}{|c|c|c|c|c|c|c|}
\hline \multicolumn{7}{|c|}{ a) Building Facade } \\
\hline & & Sum of Squares & df & Mean Square & $\mathrm{F}$ & Sig. \\
\hline \multirow[t]{3}{*}{ Irrigation frequency } & Between Groups & 2.559 & 2 & 1.279 & 3.039 & .052 \\
\hline & Within Groups & 40.831 & 97 & .421 & & \\
\hline & Total & 43.390 & 99 & & & \\
\hline \multirow[t]{3}{*}{ Effectiveness of water drainage } & Between Groups & .964 & 2 & .482 & 1.415 & .248 \\
\hline & Within Groups & 33.036 & 97 & .341 & & \\
\hline & Total & 34.000 & 99 & & & \\
\hline
\end{tabular}




\begin{tabular}{|c|c|c|c|c|c|c|}
\hline \multirow[t]{3}{*}{ Installation cost } & Between Groups & 4.539 & 2 & 2.270 & 5.443 & .006 \\
\hline & Within Groups & 40.451 & 97 & .417 & & \\
\hline & Total & 44.990 & 99 & & & \\
\hline \multirow[t]{3}{*}{ Maintenance regime } & Between Groups & 1.183 & 2 & .591 & 1.701 & .188 \\
\hline & Within Groups & 33.727 & 97 & .348 & & \\
\hline & Total & 34.910 & 99 & & & \\
\hline \multirow[t]{3}{*}{ Aesthetic requirement } & Between Groups & 1.133 & 2 & .567 & 1.299 & .277 \\
\hline & Within Groups & 42.307 & 97 & .436 & & \\
\hline & Total & 43.440 & 99 & & & \\
\hline \multirow[t]{3}{*}{ Types of plants } & Between Groups & .296 & 2 & .148 & .330 & .720 \\
\hline & Within Groups & 43.494 & 97 & .448 & & \\
\hline & Total & 43.790 & 99 & & & \\
\hline \multirow[t]{3}{*}{ Elevation (north, south, east, west) } & Between Groups & 4.484 & 2 & 2.242 & 4.117 & .019 \\
\hline & Within Groups & 52.826 & 97 & .545 & & \\
\hline & Total & 57.310 & 99 & & & \\
\hline \multirow[t]{3}{*}{ Geographical location } & Between Groups & 2.591 & 2 & 1.296 & 2.214 & .115 \\
\hline & Within Groups & 56.769 & 97 & .585 & & \\
\hline & Total & 59.360 & 99 & & & \\
\hline \multirow[t]{3}{*}{ Application (indoor or outdoor) } & Between Groups & 3.723 & 2 & 1.862 & 3.618 & .031 \\
\hline & Within Groups & 49.917 & 97 & .515 & & \\
\hline & Total & 53.640 & 99 & & & \\
\hline \multirow[t]{3}{*}{ Dimensions of VGS (height, length and width) } & Between Groups & 19.797 & 2 & 9.898 & 22.066 & .000 \\
\hline & Within Groups & 43.513 & 97 & .449 & & \\
\hline & Total & 63.310 & 99 & & & \\
\hline \multicolumn{7}{|c|}{ b) Outdoor Building Column } \\
\hline & & Sum of Squares & df & Mean Square & $\mathrm{F}$ & Sig. \\
\hline \multirow[t]{3}{*}{ Irrigation frequency } & Between Groups & 1.842 & 3 & .614 & 1.419 & .242 \\
\hline & Within Groups & 41.548 & 96 & .433 & & \\
\hline & $\overline{T o t a l}$ & 43.390 & 99 & & & \\
\hline \multirow[t]{3}{*}{ Effectiveness of water drainage } & Between Groups & .495 & 3 & .165 & .472 & .702 \\
\hline & Within Groups & 33.505 & 96 & .349 & & \\
\hline & $\overline{\text { Total }}$ & 34.000 & 99 & & & \\
\hline \multirow[t]{3}{*}{ Installation cost } & Between Groups & 2.369 & 3 & .790 & 1.779 & .156 \\
\hline & Within Groups & 42.621 & 96 & .444 & & \\
\hline & Total & 44.990 & 99 & & & \\
\hline \multirow[t]{3}{*}{ Maintenance regime } & Between Groups & 2.376 & 3 & .792 & 2.337 & .079 \\
\hline & Within Groups & 32.534 & 96 & .339 & & \\
\hline & Total & 34.910 & 99 & & & \\
\hline \multirow[t]{3}{*}{ Aesthetic requirement } & Between Groups & 1.978 & 3 & .659 & 1.527 & .212 \\
\hline & Within Groups & 41.462 & 96 & .432 & & \\
\hline & Total & 43.440 & 99 & & & \\
\hline \multirow[t]{3}{*}{ Types of plants } & Between Groups & 2.343 & 3 & .781 & 1.809 & .151 \\
\hline & Within Groups & 41.447 & 96 & .432 & & \\
\hline & Total & 43.790 & 99 & & & \\
\hline
\end{tabular}




\begin{tabular}{|c|c|c|c|c|c|c|}
\hline \multirow[t]{3}{*}{ Elevation (north, south, east, west) } & Between Groups & 2.307 & 3 & .769 & 1.342 & .265 \\
\hline & Within Groups & 55.003 & 96 & .573 & & \\
\hline & Total & 57.310 & 99 & & & \\
\hline \multirow[t]{3}{*}{ Geographical location } & Between Groups & 4.199 & 3 & 1.400 & 2.436 & .069 \\
\hline & Within Groups & 55.161 & 96 & .575 & & \\
\hline & Total & 59.360 & 99 & & & \\
\hline \multirow[t]{3}{*}{ Application (indoor or outdoor) } & Between Groups & 1.493 & 3 & .498 & .916 & .436 \\
\hline & Within Groups & 52.147 & 96 & .543 & & \\
\hline & Total & 53.640 & 99 & & & \\
\hline \multirow[t]{3}{*}{ Dimensions of VGS (height, length and width) } & Between Groups & 11.385 & 3 & 3.795 & 7.017 & .000 \\
\hline & Within Groups & 51.925 & 96 & .541 & & \\
\hline & Total & 63.310 & 99 & & & \\
\hline \multicolumn{7}{|c|}{ c) Balcony/ Rooftop Area } \\
\hline & & Sum of Squares & $d f$ & Mean Square & $\mathrm{F}$ & Sig. \\
\hline \multirow[t]{3}{*}{ Irrigation frequency } & Between Groups & .834 & 3 & .278 & .627 & .599 \\
\hline & Within Groups & 42.556 & 96 & .443 & & \\
\hline & Total & 43.390 & 99 & & & \\
\hline \multirow[t]{3}{*}{ Effectiveness of water drainage } & Between Groups & .978 & 3 & .326 & .948 & .421 \\
\hline & Within Groups & 33.022 & 96 & .344 & & \\
\hline & Total & 34.000 & 99 & & & \\
\hline \multirow[t]{3}{*}{ Installation cost } & Between Groups & .104 & 3 & .035 & .074 & .974 \\
\hline & Within Groups & 44.886 & 96 & .468 & & \\
\hline & Total & 44.990 & 99 & & & \\
\hline \multirow[t]{3}{*}{ Maintenance regime } & Between Groups & .410 & 3 & .137 & .381 & .767 \\
\hline & Within Groups & 34.500 & 96 & .359 & & \\
\hline & Total & 34.910 & 99 & & & \\
\hline \multirow[t]{3}{*}{ Aesthetic requirement } & Between Groups & 1.575 & 3 & .525 & 1.204 & .313 \\
\hline & Within Groups & 41.865 & 96 & .436 & & \\
\hline & Total & 43.440 & 99 & & & \\
\hline \multirow[t]{3}{*}{ Types of plants } & Between Groups & 2.280 & 3 & .760 & 1.758 & .160 \\
\hline & Within Groups & 41.510 & 96 & .432 & & \\
\hline & Total & 43.790 & 99 & & & \\
\hline \multirow[t]{3}{*}{ Elevation (north, south, east, west) } & Between Groups & 3.608 & 3 & 1.203 & 2.150 & .099 \\
\hline & Within Groups & 53.702 & 96 & .559 & & \\
\hline & Total & 57.310 & 99 & & & \\
\hline \multirow[t]{3}{*}{ Geographical location } & Between Groups & 1.055 & 3 & .352 & .579 & .630 \\
\hline & Within Groups & 58.305 & 96 & .607 & & \\
\hline & Total & 59.360 & 99 & & & \\
\hline \multirow[t]{3}{*}{ Application (indoor or outdoor) } & Between Groups & 2.391 & 3 & .797 & 1.493 & .221 \\
\hline & Within Groups & 51.249 & 96 & .534 & & \\
\hline & Total & 53.640 & 99 & & & \\
\hline \multirow[t]{3}{*}{ Dimensions of VGS (height, length and width) } & Between Groups & .145 & 3 & .048 & .073 & .974 \\
\hline & Within Groups & 63.165 & 96 & .658 & & \\
\hline & Total & 63.310 & 99 & & & \\
\hline
\end{tabular}




\begin{tabular}{|c|c|c|c|c|c|c|}
\hline \multicolumn{7}{|c|}{ d) Indoor Area } \\
\hline & & Sum of Squares & $\mathrm{df}$ & Mean Square & $\mathbf{F}$ & Sig. \\
\hline \multirow[t]{3}{*}{ Irrigation frequency } & Between Groups & .747 & 3 & .249 & .560 & .643 \\
\hline & Within Groups & 42.643 & 96 & .444 & & \\
\hline & Total & 43.390 & 99 & & & \\
\hline \multirow[t]{3}{*}{ Effectiveness of water drainage } & Between Groups & 3.639 & 3 & 1.213 & 3.836 & .012 \\
\hline & Within Groups & 30.361 & 96 & .316 & & \\
\hline & Total & 34.000 & 99 & & & \\
\hline \multirow[t]{3}{*}{ Installation cost } & Between Groups & .914 & 3 & .305 & .663 & .577 \\
\hline & Within Groups & 44.076 & 96 & .459 & & \\
\hline & Total & 44.990 & 99 & & & \\
\hline \multirow[t]{3}{*}{ Maintenance regime } & Between Groups & .197 & 3 & .066 & .181 & .909 \\
\hline & Within Groups & 34.713 & 96 & .362 & & \\
\hline & Total & 34.910 & 99 & & & \\
\hline \multirow[t]{3}{*}{ Aesthetic requirement } & Between Groups & 1.834 & 3 & .611 & 1.411 & .244 \\
\hline & Within Groups & 41.606 & 96 & .433 & & \\
\hline & Total & 43.440 & 99 & & & \\
\hline \multirow[t]{3}{*}{ Types of plants } & Between Groups & 2.966 & 3 & .989 & 2.325 & .080 \\
\hline & Within Groups & 40.824 & 96 & .425 & & \\
\hline & Total & 43.790 & 99 & & & \\
\hline \multirow[t]{3}{*}{ Elevation (north, south, east, west) } & Between Groups & 2.896 & 3 & .965 & 1.703 & .172 \\
\hline & Within Groups & 54.414 & 96 & .567 & & \\
\hline & Total & 57.310 & 99 & & & \\
\hline \multirow[t]{3}{*}{ Geographical location } & Between Groups & 1.780 & 3 & .593 & .989 & .401 \\
\hline & Within Groups & 57.580 & 96 & .600 & & \\
\hline & Total & 59.360 & 99 & & & \\
\hline \multirow[t]{3}{*}{ Application (indoor or outdoor) } & Between Groups & 2.845 & 3 & .948 & 1.792 & .154 \\
\hline & Within Groups & 50.795 & 96 & .529 & & \\
\hline & Total & 53.640 & 99 & & & \\
\hline \multirow[t]{3}{*}{ Dimensions of VGS (height, length and width) } & Between Groups & 3.124 & 3 & 1.041 & 1.661 & .181 \\
\hline & Within Groups & 60.186 & 96 & .627 & & \\
\hline & Total & 63.310 & 99 & & & \\
\hline
\end{tabular}

An ANOVA analysis was conducted towards considerations in VGS irrigation system against different building locations. Table 9 shows both "water frequency and water volume" and "timer-controlled pumping system" are significantly associated with "building façade", with p-values of 0.004 and 0.014 , respectively. However, "rooting materials" $(p=0.011)$ and "soil sensor" ( $p=0.008)$ are significant to "indoor area." The independent variables "outdoor building column" and "balcony/rooftop area" are not statistically associated with any consideration in VGS irrigation system design.

Figure 5 presents the endogenous variable variance, analyzed using the PLS algorithm. Each circle in the PLS-SEM diagram (Figure 5) demonstrates the coefficient of determination (R2) for each variable. $\mathrm{R}^{2}$ values explain significance between two variables, where a value $>0.75$ represents a substantial relationship, 0.50 is moderate, and 0.25 is weak. Importantly, the R2 of the "Criteria in Choosing VGS Irrigation System" endogenous latent variable is 
TABLE 9. Considerations in Vertical Greenery System (VGS) irrigation system against different buildina locations

\begin{tabular}{|c|c|c|c|c|c|c|}
\hline \multicolumn{7}{|c|}{ a) Building Façade } \\
\hline & & Sum of Squares & df & Mean Square & $F$ & Sig. \\
\hline \multirow[t]{3}{*}{ Gravitational force due to vertical alignment } & Between Groups & 3.009 & 2 & 1.505 & 2.920 & .059 \\
\hline & Within Groups & 49.991 & 97 & .515 & & \\
\hline & Total & 53.000 & 99 & & & \\
\hline \multirow[t]{3}{*}{ Water volume \& water frequency } & Between Groups & 3.998 & 2 & 1.999 & 5.869 & .004 \\
\hline & Within Groups & 33.042 & 97 & 341 & & \\
\hline & Total & 37.040 & 99 & & & \\
\hline \multirow[t]{3}{*}{ Timer-controlled pumping system } & Between Groups & 3.606 & 2 & 1.803 & 4.468 & .014 \\
\hline & Within Groups & 39.144 & 97 & .404 & & \\
\hline & Total & 42.750 & 99 & & & \\
\hline \multirow[t]{3}{*}{ Rooting materials (e.g. coconut husk and felt) } & Between Groups & .089 & 2 & .045 & .085 & .919 \\
\hline & Within Groups & 50.911 & 97 & .525 & & \\
\hline & Total & 51.000 & 99 & & & \\
\hline \multirow[t]{3}{*}{ Soil sensor (i.e. temperature, $\mathrm{pH}$, moisture etc.) } & Between Groups & 1.240 & 2 & 620 & 1.297 & .278 \\
\hline & Within Groups & 46.400 & 97 & 478 & & \\
\hline & Total & 47.640 & 99 & & & \\
\hline \multirow[t]{3}{*}{ Planter cell design (tray system) } & Between Groups & .051 & 2 & .025 & .046 & .955 \\
\hline & Within Groups & 53.659 & 97 & .553 & & \\
\hline & Total & 53.710 & 99 & & & \\
\hline \multicolumn{7}{|c|}{ b) Outdoor Building Column } \\
\hline & & Sum of Squares & $d f$ & Mean Square & $\mathrm{F}$ & Sig. \\
\hline \multirow[t]{3}{*}{ Gravitational force due to vertical alignment } & Between Groups & 1.655 & 3 & .552 & 1.031 & .382 \\
\hline & Within Groups & 51.345 & 96 & .535 & & \\
\hline & Total & 53.000 & 99 & & & \\
\hline \multirow[t]{3}{*}{ Water volume \& water frequency } & Between Groups & .478 & 3 & .159 & .418 & .740 \\
\hline & Within Groups & 36.562 & 96 & .381 & & \\
\hline & Total & 37.040 & 99 & & & \\
\hline \multirow[t]{3}{*}{ Timer-controlled pumping system } & Between Groups & 2.638 & 3 & .879 & 2.105 & .105 \\
\hline & Within Groups & 40.112 & 96 & .418 & & \\
\hline & Total & 42.750 & 99 & & & \\
\hline \multirow[t]{3}{*}{ Rooting materials (e.g. coconut husk and felt) } & Between Groups & .121 & 3 & .040 & .076 & .973 \\
\hline & Within Groups & 50.879 & 96 & .530 & & \\
\hline & Total & 51.000 & 99 & & & \\
\hline \multirow[t]{3}{*}{ Soil sensor (i.e. temperature, $\mathrm{pH}$, moisture etc.) } & Between Groups & 2.343 & 3 & .781 & 1.655 & .182 \\
\hline & Within Groups & 45.297 & 96 & .472 & & \\
\hline & $\overline{\text { Total }}$ & 47.640 & 99 & & & \\
\hline \multirow[t]{3}{*}{ Planter cell design (tray system) } & Between Groups & 1.036 & 3 & .345 & .630 & .598 \\
\hline & Within Groups & 52.674 & 96 & .549 & & \\
\hline & Total & 53.710 & 99 & & & \\
\hline
\end{tabular}




\begin{tabular}{|c|c|c|c|c|c|c|}
\hline \multicolumn{7}{|c|}{ c) Balcony/ Rooftop Area } \\
\hline & & Sum of Squares & $\mathrm{df}$ & Mean Square & $F$ & Sig. \\
\hline \multirow[t]{3}{*}{ Gravitational force due to vertical alignment } & Between Groups & 1.691 & $\beta$ & .564 & 1.054 & .372 \\
\hline & Within Groups & 51.309 & 96 & .534 & & \\
\hline & Total & 53.000 & 99 & & & \\
\hline \multirow[t]{3}{*}{ Water volume \& water frequency } & Between Groups & 351 & $\beta$ & .117 & .306 & .821 \\
\hline & Within Groups & 36.689 & 96 & 382 & & \\
\hline & Total & 37.040 & 99 & & & \\
\hline \multirow[t]{3}{*}{ Timer-controlled pumping system } & Between Groups & 1.539 & $\beta$ & .513 & 1.195 & 316 \\
\hline & Within Groups & 41.211 & 96 & 429 & & \\
\hline & Total & 42.750 & 99 & & & \\
\hline \multirow[t]{3}{*}{ Rooting materials (e.g. coconut husk and felt) } & Between Groups & .947 & $\beta$ & 316 & .606 & .613 \\
\hline & Within Groups & 50.053 & 96 & .521 & & \\
\hline & Total & 51.000 & 99 & & & \\
\hline \multirow[t]{3}{*}{ Soil sensor (i.e. temperature, $\mathrm{pH}$, moisture etc.) } & Between Groups & 1.766 & $\beta$ & .589 & 1.232 & .302 \\
\hline & Within Groups & 45.874 & 96 & .478 & & \\
\hline & Total & 47.640 & 99 & & & \\
\hline \multirow[t]{3}{*}{ Planter cell design (tray system) } & Between Groups & .972 & $\beta$ & 324 & .590 & .623 \\
\hline & Within Groups & 52.738 & 96 & .549 & & \\
\hline & Total & 53.710 & 99 & & & \\
\hline \multicolumn{7}{|c|}{ d) Indoor Area } \\
\hline & & Sum of Squares & $\mathrm{df}$ & Mean Square & $\mathbf{F}$ & Sig. \\
\hline \multirow[t]{3}{*}{ Gravitational force due to vertical alignment } & Between Groups & 2.165 & 3 & 722 & 1.363 & .259 \\
\hline & Within Groups & 50.835 & 96 & .530 & & \\
\hline & Total & 53.000 & 99 & & & \\
\hline \multirow[t]{3}{*}{ Water volume \& water frequency } & Between Groups & 1.987 & 3 & .662 & 1.814 & 150 \\
\hline & Within Groups & 35.053 & 96 & .365 & & \\
\hline & Total & 37.040 & 99 & & & \\
\hline \multirow[t]{3}{*}{ Timer-controlled pumping system } & Between Groups & 1.612 & 3 & .537 & 1.254 & .295 \\
\hline & Within Groups & 41.138 & 96 & .429 & & \\
\hline & Total & 42.750 & 99 & & & \\
\hline \multirow[t]{3}{*}{ Rooting materials (e.g. coconut husk and felt) } & Between Groups & 5.866 & 3 & 1.955 & 4.159 & .008 \\
\hline & Within Groups & 45.134 & 96 & 470 & & \\
\hline & Total & 51.000 & 99 & & & \\
\hline \multirow[t]{3}{*}{ Soil sensor (i.e. temperature, $\mathrm{pH}$, moisture etc.) } & Between Groups & 5.202 & 3 & 1.734 & 3.923 & 011 \\
\hline & Within Groups & 42.438 & 96 & .442 & & \\
\hline & Total & 47.640 & 99 & & & \\
\hline \multirow[t]{3}{*}{ Planter cell design (tray system) } & Between Groups & 2.583 & 3 & .861 & 1.617 & 191 \\
\hline & Within Groups & 51.127 & 96 & .533 & & \\
\hline & Total & 53.710 & 99 & & & \\
\hline
\end{tabular}


0.423; this is the highest among the three variables, which means that the variable "Location of VGS Implementation" is statistically significant. However, it does not exert a strong effect on the independent variable, as the value shown only indicates a moderate strength. Meanwhile, the two variables "VGS Implementation Factors" (0.214) and "Considerations in VGS Irrigation System" (0.134) only provide a weak explanation of the variance in "Location of VGS Implementation"; however, the coefficients of determination are below 0.25 , indicating the exogenous variables do not significantly explain the variance in the endogenous variables.

FIGURE 5. Endogenous variable variance in Partial Least Square (PLS) algorithm

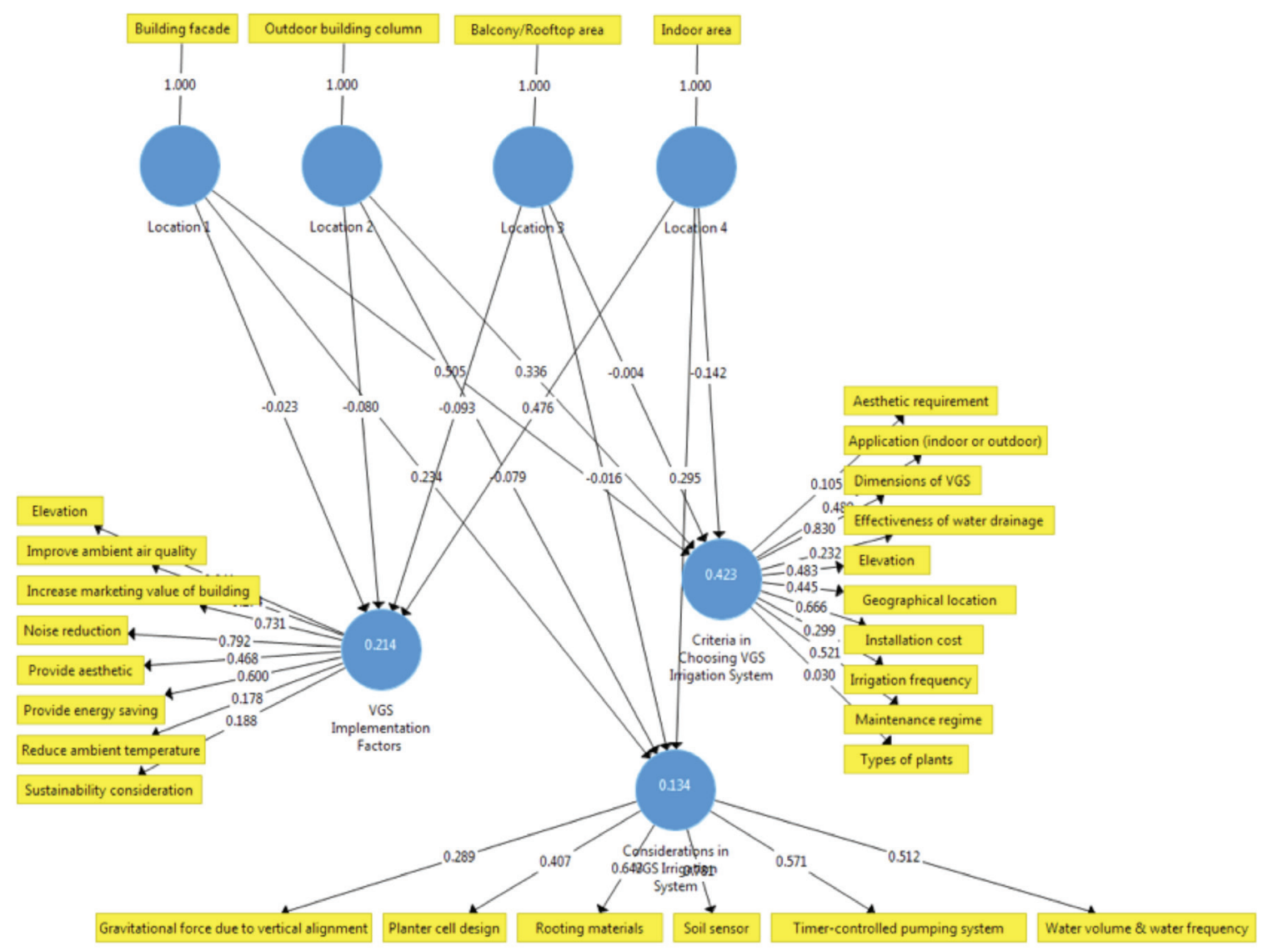

\section{DISCUSSION OF FINDINGS}

Most respondents believe that the watering schedule is the most important consideration for VGS irrigation system, which is aligned with results from Stirzaker (1999); this indicates a close relationship between the irrigation scheduling device and the success of irrigation systems. However, insufficient accuracy in the device will fail to solve problems associated with excess water diverted for irrigation. Watering schedules concern water volumes and watering frequency. Wei et al. (2003) also indicate that the emitter used to moderate water flow and water speed in drip irrigation systems is a key component for keeping a steady flow rate. Meanwhile, a drip line system can be used to keep the water volume precise and ensure the accuracy in water distribution (Hopkins and Goodwin, 2011). Nevertheless, the survey results show that respondents considered timer-controlled pumping systems a key component 
of the irrigation system - and this is highly correlated with precise water distribution in VGS. Hopkins and Goodwin (2011) support that the vertical alignment within the VGS structure presents difficulties in overcoming gravity. Pumping systems with timer controllers are crucial to efforts to generate sufficient pressure for water distribution. Soil sensors that monitor moisture levels in VGS are placed in plants' root zones to determine where water is necessary. It is important to control the irrigation system to optimize the soil moisture level. Technically, the planter cell is used in the carrier systems to hold substrate media or hydroponics cultures for nutrient supply, as suggested by Dunnett and Kingsbury (2004). While in soil-based VGS, the planter cell holds the growth media for plant material sustainability (Almusaed, 2011).

Regarding the considerations in choosing the VGS irrigation system, the consideration of maintenance regime and installation costs were shown to have slight differences in their mean values. Maintenance regimes are perceived by the respondents to be closely related to the installation costs. A comprehensive maintenance regime is necessary for the VGS user to ensure that no extra cost is incurred throughout the life cycle. Maintenance always involves significant cost as it is labor intensive; thus, maintenance costs can become a critical issue when VGS is employed. The issue of water drainage effectiveness must be addressed to ensure the proper management of the system. Water accumulation in a VGS will hinder plant growth, leading to system failure. Shallow rooting and drought-tolerant plants are used in vegetated walls as few weeds survive in the shallow soil. The performance of irrigation systems is evaluated based on the application efficiency; thus, irrigation frequency must be effectively controlled. Also, our results indicate respondents have a high level of agreement on the importance of the aesthetic requirements for tropical VGS irrigation systems, showing how VGS has a positive visual impact on the environment (Wang et al., 2016). However, the presence of VGS sometimes distracts from the aesthetics of the building and may, therefore, reduce the value of the property if an undesirable visual outlook is provided. Plant types also play a crucial role in determining the success of VGS irrigation system; Almusaed (2011) points out the importance of having sufficient knowledge of plant behaviors and characteristics. There is a correlation between the green layer and building materials durability. Much of the functionality of VGS is influenced by plant types used.

Respondents believe that ambient air quality can be improved through VGS installation. According to Wong et al. (2010), greenery is a key element to consolidate a new sustainable urban lifestyle by strengthening the partnership between nature and the city. Hence, the concept of 'green infrastructure' has been adopted to provide an environmentally friendly function when mitigating the UHI impact and reducing ambient temperature (Pérez et al., 2014). VGS supports various cooling methods, e.g., shading, reflection of solar radiation, convective shielding, thermal insulation, and evapotranspirative cooling (Taha, 1997). Respondents do not believe that VGS impacts on noise reduction, which indicates a widespread lack of appreciation of the acoustic functioning of VGS outlined in Perini et al. (2012). Respondents believe the building façade is the best location for VGS irrigation systems. There will be more problems developing within the irrigation system if VGS is applied indoors, as noted by Almusaed (2011).

This research is important because while VGS is an important component of sustainable urbanization, much more research is required to understand the technical elements required for implementation. Together, there are a variety of factors relating to the characteristics of plants, locations, orientations, microclimatic, and irrigation systems that professionals need to understand when designing and implementing the VGS. While some of these factors have 
been carefully studied, this research examined the interrelationship between them and the awareness that working professionals have regarding these interrelationships. Given the survey results, it is clear that professionals still have gaps in their understanding of VGS implementation, and this inspires a range of follow-up research questions.

\section{CONCLUSIONS AND RECOMMENDATIONS}

This study achieved two outcomes. First, it provides detailed discussions on the design and installation of the tropical VGS irrigation systems. Key plant characteristics have been identified to help potential users to select appropriate VGS irrigation systems. This research has determined suitable locations, orientations, and microclimatic conditions for VGS implementations to prevent system failure. The most suitable location for VGS irrigation system implementation is on the building façade. Selection of the plant type plays a crucial role in determining the success of VGS irrigation system installations. Watering schedules are the most important consideration when installing a VGS irrigation system. Pumping systems with timer controllers are crucial to ensure sufficient water pressure for distribution. It is suggested that further research on determining costs of VGS installation in various building structures be conducted to determine a suitable cost-benefit analysis. Second, this study improved our understanding of how aware professionals are of the interconnected nature of many of these issues and criteria. Respondents are very aware of the importance of the watering systems and schedules. The costs of installation are well-understood but the costs associated with longterm maintenance are less clearly understood despite the significance for the long-term viability of the project. While most respondents were aware of air quality benefits from VGS, few seemed to realize the noise reduction benefits that can be obtained.

Further research focused on establishing the technical requirements for irrigation scheduling is recommended to improve the application efficiency. A limitation of this study was the exclusion of the role of governance, support structures, and constructive dialogue at the local government level to promote the transition to sustainable solutions in the urban environment. Although these have been shown to be important, they were not included in this study and may need to be included in future research as an important consideration that can influence the designers and professionals surveyed in this research.

\section{REFERENCES}

Adamala, S., Raghuwanshi, N.S., Mishra, A. 2014. Development of Surface Irrigation Systems Design and Evaluation Software (SIDES). Computers and Electronics in Agriculture, 100, 100-109. doi:10.1016/j. compag.2013.11.004

Adams, J. 2010. Vegetation: Climate interaction. Berlin, Heidelberg: Springer.

Alaba, C.S.M., Chichioco-Hernandez, C.L. 2014. 15-Lipoxygenase inhibition of Commelina benghalensis, Tradescantia fluminensis, Tradescantia zebrine. Asian Pacific Journal of Tropical Biomedicine, 4(3), 184-188.

Albaji, M., Golabi, M., Boroomand, S. 2015. Investigation of surface, sprinkler and drip irrigation methods based on the parametric evaluation approach in Jaizan Plain. Journal of the Saudi Society of Agricultural Sciences, 14(1), 1-10. doi:10.1016/j.jssas.2013.11.001

Almusaed, A. 2011. Biophilic and Bioclimatic Architecture: Analytical Therapy for the Next Generation of Passive Sustainable Architecture. London: Springer.

Bhatnagar, P., Srivastava, R. 2003. Gravity-fed drip irrigation system for hilly terraces of the northwest Himalayas. Irrigation Science, 21(4), 151-157. doi:10.1007/s00271-002-0058-y 
Coutts, A.M., Tapper, N.J., Beringer, J., Loughnan, M., Demuzere, M. 2012. Watering our cities: The capacity for Water Sensitive Urban Design to support urban cooling and improve human thermal comfort in the Australian context. Progress in Physical Geography, 37, 2-28. doi:10.1177/0309133312461032

de Jong, M., Joss, S., Schraven, D., Zhan, C., Weijnen, M. 2015. Sustainable-smart-resilient-low carbon-ecoknowledge cities; making sense of a multitude of concepts promoting sustainable urbanization. Journal of Cleaner Production, 109(16), 25-38. doi:10.1016/j.jclepro.2015.02.004

Diyana Rosli, A., Damanhuri, N.S., Ismail, N., Hamid, S.A., Zulhanip, A.Z., Ismail, N., Leh, N.A.M. 2012. Intelligence irrigation system employing the use of solar PV. 2012 IEEE International Conference on Control System, Computing and Engineering, 458-461. doi:10.1109/ICCSCE.2012.6487189

Djedjig, R., Bozonnet, E., Belarbi, R. 2015. Analysis of thermal effects of vegetated envelopes: Integration of a validated model in a building energy simulation program. Energy and Buildings, 86, 93-103. doi:10.1016/j. enbuild.2014.09.057

Dunnett, N., Kingsbury, N. 2004. Planting Green Roofs and Living Walls. Oregon: Timber Press.

Ertek, a., Yilmaz, H. 2014. The agricultural perspective on water conservation in Turkey. Agricultural Water Management, 143, 151-158. doi:10.1016/j.agwat.2014.07.009

Fereres, E., Goldhamer, D.A., Parsons, L.R. 2003. Irrigation Water Management of Horticultural Crops. HortScience, 38, 1036-1042.

Fernandez-Canero, R., Urrestarazu, L.P., Franco Salas, A. 2011. Assessment of the Cooling Potential of an Indoor Living Wall using Different Substrates in a Warm Climate. Indoor and Built Environment, 21(5), 642-650.

Gärdenäs, a. I., Hopmans, J.W., Hanson, B.R., Šimůnek, J. 2005. Two-dimensional modeling of nitrate leaching for various fertigation scenarios under micro-irrigation. Agricultural Water Management, 74, $219-242$. doi:10.1016/j.agwat.2004.11.011

Hamann, R., April, K. 2013. On the role and capabilities of collaborative intermediary organisations in urban sustainability transitions. Journal of Cleaner Production, 50, 12-21. doi:10.1016/j.jclepro.2012.11.017

Hopkins, G., Goodwin, C. 2011. Living Architecture: Green Roofs and Walls. Clayton South VIC, Australia: Csiro Publishing.

Hunter, A.M., Williams, N.S.G., Rayner, J.P., Aye, L., Hes, D., Livesley, S.J. 2014. Quantifying the thermal performance of green façades: A critical review. Ecological Engineering, 63, 102-113. doi:10.1016/j. ecoleng.2013.12.021

Hvoslef-Eide, A.K. 1991. Mother plant temperature effects on growth of in vitro propagated daughter plants of Nephrolepis exaltata (L.) Schott. Scientia Horticulturae, 47(1-2), 149-156.

James, L.G. 1987. Farm Irrigation Systems and System Design Fundamentals, in: Principles of Farm Irrigation System Design, London: Wiley, pp. 61-109.

Jim, C.Y., He, H. 2011. Estimating heat flux transmission of vertical greenery ecosystem. Ecological Engineering, 37, 1112-1122. doi:10.1016/j.ecoleng.2011.02.005

Köhler, M. 2008. Green facades: a view back and some visions. Urban Ecosyst. 11, 423-436. doi:10.1007/ s11252-008-0063-x

Mattis, P.R., Hershey, D.R. 1992. Iron Deficiency Stress Response of Epipremnum aureum and Philodendron scandens Subspecies Oxycardium. Journal of Plant Physiology, 139(4), 498-502.

Mazzali, U., Peron, F., Romagnoni, P., Pulselli, R. M., Bastianoni, S. 2013. Experimental investigation on the energy performance of Living Walls in a temperate climate. Building and Environment, 64, 57-66.

Morton, C.V. 1957. Observations on Cultivated Ferns, IV: The Species of Davallia. American Fern Journal, 47(4), 143-144.

Pandey, A.K., Pandey, M., Tripathi, B.D. 2015. Air Pollution Tolerance Index of climber plant species to develop Vertical Greenery Systems in a polluted tropical city. Landscape and Urban Planning, 144, 119-127.

Pulselli, R.M., Pulselli, F.M., Mazzali, U., Peron, F., Bastianoni, S. 2014. Emergy based eval-uation of environmental performances of Living Wall and Grass Wall systems. Energy and Buildings, 73, 200-211.

Pérez, G., Coma, J., Martorell, I., Cabeza, L.F. 2014. Vertical Greenery Systems (VGS) for energy saving in buildings: A review. Renewable \& Sustainable Energy Reviews, 39, 139-165. doi:10.1016/j.rser.2014.07.055

Perini, K., Ottelé, M., Haas, E.M., Raiteri, R. 2012. Vertical greening systems, a process tree for green façades and living walls. Urban Ecosystems, 16, 265-277. doi:10.1007/s11252-012-0262-3 
Puppim de Oliveira, J.A., Doll, C.N.H., Balaban, O., Jiang, P., Dreyfus, M., Suwa, A., Moreno-Peñaranda, R., Dirgahayani, P. 2013. Green economy and governance in cities: Assessing good governance in key urban economic processes. Journal of Cleaner Production, 58, 138-152. doi:10.1016/j.jclepro.2013.07.043

Rahil, M.H., Qanadillo, A. 2015. Effects of different irrigation regimes on yield and water use efficiency of cucumber crop. Agricultural Water Management, 148, 10-15. doi:10.1016/j.agwat.2014.09.005

Ren, Z., Peng, H., Li, Z. 2016. The rapid climate change-caused dichotomy on subtropical evergreen broadleaved forest in Yunnan: Reduction in habitat diversity and increase in species diversity. Plant Diversity, doi: 10.1016/j.pld.2016.04.003.

Salant, P., Dillman, D.A., 1994. How to conduct your own survey. Wiley, Michigan.

Smedby, N., Neij, L. 2013. Experiences in urban governance for sustainability: The Constructive Dialogue in Swedish municipalities. Journal of Cleaner Production, 50, 148-158. doi:10.1016/j.jclepro.2012.11.044

Stirzaker, R.J. 1999. The problem of irrigated horticulture : matching the biophysical efficiency with the economic efficiency. Agroforestry Systems, 45, 187-202.

Šuklje, T., Medved, S., Arkar, C., 2013. An Experimental Study on a Microclimatic Layer of a Bionic Façade Inspired by Vertical Greenery. Journal of Bionic Engineering, 10, 177-185. doi:10.1016/ S1672-6529(13)60213-9

Vogelezang, J.V.M. 1991. Effect of root-zone and air temperature on growth, ornamental value and keepability of Ficus benjamina and Schefflera arboricola 'Compacta'. Scientia Horticulturae, 46(3-4), 301-313.

Taha, H. 1997. Urban climates and heat islands: albedo, evapotranspiration, and anthropogenic heat. Energy and Buildings, 25, 99-103.

Wang, C., Er, S.S., Abdul-Rahman, H. 2016. Indoor vertical greenery system in urban tropics. Indoor and Built Environment, 25(2), 340-356. doi:10.1177/1420326X14550508

Wei, Z., Tang, Y., Zhao, W., Lu, B. 2003. Rapid development technique for drip irrigation emitters. Rapid Prototyping Journal, 9, 104-110. doi:10.1108/13552540310467112

Wilde, M.D., Buisson, E., Ratovoson, F., Randrianaivo, R., Carrière, S.M., Ii, P.P.L. 2012. Vegetation dynamics in a corridor between protected areas after slash-and-burn cultivation in south-eastern Madagascar. Agriculture, Ecosystems \& Environment, 159, 1-8.

Woltering, E.J. 1987. Effects of ethylene on ornamental pot plants: A classification. Scientia Horticulturae, 31(3-4), 283-294.

Wong, N.H., Kwang Tan, A.Y., Chen, Y., Sekar, K., Tan, P.Y., Chan, D., Chiang, K., Wong, N.C. 2010. Thermal evaluation of vertical greenery systems for building walls. Building and Environment, 45, 663-672. doi:10.1016/j.buildenv.2009.08.005

Wong, N.H., Tan, A.Y.K., Tan, P.Y., Wong, N.C. 2009. Energy simulation of vertical greenery systems. Energy and Buildings, 41, 1401-1408. doi:10.1016/j.enbuild.2009.08.010

Yu, Y., Liu, L., Liu, J., Wang, J. 2009. Plant Regeneration by Callus-Mediated Protocorm-Like Body Induction of Anthurium andraeanum Hort. Agricultural Sciences in China, 8(5), 572-577.

Zhang, X. 2016. Sustainable urbanization: A bi-dimensional matrix model. Journal of Cleaner Production, 134, 425-433. doi:10.1016/j.jclepro.2015.08.036

\section{APPENDIX A}

\section{Questionnaires Form}

All information is strictly confidential and will not be disclosed

\section{SECTION A \\ General Information}

1.Gender

$\square$ Male $\square$ Female

2.Age

$\square$ Below $20 \quad \square 21$ to $25 \quad \square 26$ to $30 \quad \square 31$ and above 
3.Education Level

$\square$ Primary $\square$ Secondary $\square$ Tertiary

4.Please state your job

$\square$ Architect $\square$ Quantity Surveyor $\square$ Contractor $\square$ Project Manager

$\square$ Employer

$\square$ Others, please specify

$\square$ Student (please state your professional field):

\section{SECTION B}

\section{Understanding on Vertical Greenery System (VGS)}

1. Have you heard about vertical greenery system (VGS) / green wall / green façade before?

$\square$ Yes $\square$ No

2.Have you seen any vertical greenery system (VGS) around you?

$\square$ Yes $\square$ No

If yes, where is the VGS being applied?

$\square$ Indoor $\square$ Outdoor (external wall as building façade)

3.Do you know vertical greenery system (VGS) can be applied in places with different shading, i.e. different receivable light intensity?

$\square$ Yes $\square$ No

4.Do you think irrigation system (watering system) is critical factor to success of VGS?

$\square$ Yes $\square$ No

\section{SECTION C}

\section{Importance of Considerations in VGS Irrigation System}

1.Please rank the importance of considerations in irrigation system of vertical greenery system (VGS) Note:

\begin{tabular}{|c|c|c|c|}
\hline 1 & 2 & 3 & 4 \\
\hline Strongly disagree & Disagree & Agree & Strongly agree \\
\hline
\end{tabular}

\begin{tabular}{|l|l|l|l|l|l|}
\hline No & \multicolumn{1}{|c|}{ Considerations } & 1 & 2 & 3 & 4 \\
\hline 1. & $\begin{array}{l}\text { Gravitational force due to vertical } \\
\text { alignment }\end{array}$ & & & & \\
\hline 2. & Water volume \& water frequency & & & & \\
\hline 3. & Timer-controlled pumping system & & & & \\
\hline 4. & $\begin{array}{l}\text { Rooting materials (e.g. coconut husk } \\
\text { and felt) }\end{array}$ & & & & \\
\hline 5. & $\begin{array}{l}\text { Soil sensor (i.e. temperature, } \mathrm{pH}, \\
\text { moisture etc.) }\end{array}$ & & & & \\
\hline 6. & Planter cell design (tray system) & & & & \\
\hline
\end{tabular}




\section{SECTION D}

\section{Criteria in Choosing VGS Irrigation System}

1.Please rank the criteria in choosing vertical greenery system (VGS) from the perspective of irrigation system Note:

\begin{tabular}{|c|c|c|c|}
\hline 1 & 2 & 3 & 4 \\
\hline Strongly disagree & Disagree & Agree & Strongly agree \\
\hline
\end{tabular}

\begin{tabular}{|l|l|l|l|l|l|}
\hline No & \multicolumn{1}{|c|}{ Decision Criteria } & 1 & 2 & 3 & 4 \\
\hline 1. & Irrigation frequency & & & & \\
\hline 2. & Effectiveness of water drainage & & & & \\
\hline 3. & Installation cost & & & & \\
\hline 4. & Maintenance regime & & & & \\
\hline 5. & Aesthetic requirement & & & \\
\hline 6. & Types of plants & & & & \\
\hline 7. & Elevation (north, south, east, west) & & & & \\
\hline 8. & Geographical location & & & & \\
\hline 9. & Application (indoor or outdoor) & & & \\
\hline 10. & $\begin{array}{l}\text { Dimensions of VGS (height, length and } \\
\text { width) }\end{array}$ & & & & \\
\hline
\end{tabular}

\section{SECTION E}

Preferences on VGS implementation

Note:

\begin{tabular}{|c|c|c|c|}
\hline 1 & 2 & 3 & 4 \\
\hline Strongly disagree & Disagree & Agree & Strongly agree \\
\hline
\end{tabular}


1.Please rank the factors for (possible) implementation of vertical greenery system (VGS) in your building

\begin{tabular}{|l|l|l|l|l|l|}
\hline No & \multicolumn{1}{|c|}{ Factors } & 1 & 2 & 3 & 4 \\
\hline 1. & Improve ambient air quality & & & & \\
\hline 2. & Reduce ambient temperature & & & & \\
\hline 3. & Provide aesthetic & & & & \\
\hline 4. & Provide energy saving & & & & \\
\hline 5. & Noise reduction & & & & \\
\hline 6. & Increase marketing value of building & & & & \\
\hline 7. & Elevation (north, south, east, west) & & & & \\
\hline 8. & Sustainability consideration & & & & \\
\hline
\end{tabular}

2.Please rank the most suitable location for vertical greenery system by taking consideration on irrigation system

\begin{tabular}{|l|l|l|l|l|l|}
\hline No & \multicolumn{1}{|c|}{ Location } & 1 & 2 & 3 & 4 \\
\hline 1. & As building facade & & & & \\
\hline 2. & As column of building (outdoor) & & & & \\
\hline 3. & Place at balcony / rooftop area & & & & \\
\hline 4. & Place at indoor area & & & & \\
\hline
\end{tabular}

